\title{
26. NEW SPECIES OF DINOCYSTS AND A NEW SPECIES OF ACRITARCH FROM THE UPPER MIOCENE AND LOWERMOST PLIOCENE, ODP LEG 105, SITE 646, LABRADOR SEA ${ }^{1}$
}

\author{
Martin J. Head, ${ }^{2}$ Geoffrey Norris, ${ }^{2}$ and Peta J. Mudie ${ }^{3}$
}

\begin{abstract}
Three new dinocyst genera, 14 new dinocyst species, and one new acritarch species are described from the upper Miocene to lowermost Pliocene Site 646 in the Labrador Sea. The new genera described are Habibacysta, Cristadinium, and Muraticysta. The new dinocyst species described are Capillicysta gloriana, Cerebrocysta? namocensis, Corrudinium? labradori, Cristadinium cristatoserratum, Cristadinium diminutivum, Gongylodinium serratum, Habibacysta tectata, Impagidinium fenestroseptatum, Muraticysta microornata, Nematosphaeropsis major, Operculodinium? eirikianum, Operculodinium janduchenei, Selenopemphix dionaeacysta, and Selenopemphix? indentata. A new acritarch species, Cymatiosphaera? invaginata is also described.
\end{abstract}

\section{INTRODUCTION}

Site 646 of Leg 105 is located in the southeastern Labrador Sea at $58^{\circ} 12.559^{\prime} \mathrm{N}, 48^{\circ} 22.147^{\prime} \mathrm{W}$, about $200 \mathrm{~km}$ to the southsouthwest of the southern tip of the Greenland continental shelf (Fig. 1). Hole 646B was drilled to a total depth of 766.7 meters below seafloor (mbsf) in a water depth of 3450 meters below sealevel (mbsl) and terminated in sediments of late Miocene age.

Detailed results of palynological investigations into the late Miocene and earliest Pliocene of Site 646 are reported by Head et al. (a, this volume). Here, we describe the new taxa encountered during this study. The reader is referred to Head et al. (a, this volume) for related stratigraphic data, including discussion of biostratigraphy, paleoecology, and general geology.

Samples were processed, examined, and photographed by the shore-based method outlined in Head et al. (a, this volume). Stratigraphic distribution of new taxa through the interval studied is shown in Table 1. Abundances shown in Table 1 are not generated from counts of individual palynomorphs but are based on relative visual estimates of the total dinocyst assemblages. England Finder coordinates are given for the location of all illustrated specimens, and in both the plate captions and text these are preceded by the slide number shown in parentheses, which in turn is preceded by the sample number. The abbreviations for bright fleld (BF), interference contrast (IC), and scanning electron microscope (SEM) in the plate captions denote the microscope system used for each figure. Dimensions of figured specimens are also given in the plate captions. Transmitted light photographs (BF and IC) were taken with a Leitz Dialux microscope fitted with a Leitz vario-orthomat 2 photo attachment, using Ilford Pan-F film. All slides containing holotype material are housed in the palynology collection of the Royal Ontario Museum, Toronto, Ontario.

\section{SYSTEMATIC DESCRIPTIONS}

Division PYRRHOPHYTA Pascher, 1914

Class DINOPHYCEAE Fritsch, 1929

Order PERIDINIALES Haeckel, 1894

Genus CAPILLICYSTA Matsuoka and Bujak in

Matsuoka et al., 1987

Discussion. Comparisons of Capillicysta to other similar genera are given in Matsuoka and Bujak (in Matsuoka et al., 1987, p. 226), but

\footnotetext{
${ }^{1}$ Srivastava, S. P., Arthur, M., Clement, B., et al., 1989. Proc. ODP, Sci. Results, 105: College Station, TX (Ocean Drilling Program).

2 Department of Geology, University of Toronto, Ontario M5S 3B1, Canada.

${ }^{3}$ Geological Survey of Canada, Atlantic Geoscience Centre, Box 1006, Dartmouth, Nova Scotia. B2Y 4A2, Canada.
}

note that Capillicysta differs from Gippslandia Stover and Williams, 1987 in having a brown cyst wall with pronounced endophragm and narrower hexa-intercalary archeopyle.

\section{Capillicysta gloriana $\mathrm{n} . \mathrm{sp}$.}

(Pl. 5, Figs. 4, 8, 10-12)

Holotype. Plate 5, Figures 11, 12. Sample 105-646B-62X-2, 139-141 $\mathrm{cm} ;(2) \mathrm{G} 46 / 2$.

Derivation of name. Named in deference to the hurricane "Gloria," which threatened to jeopardize drilling objectives at Site 646 in the Labrador Sea.

Diagnosis. Cysts generally cornucavate, dorsoventrally compressed, and brown in color. Pericyst outline peridinioid with a short apical horn and two longer antapical horns of aproximately equal length. Endocyst outline circular to rounded pentagonal, sometimes with a small apical prominence, having a smooth to irregularly granulate surface and a medium brown color. Pericyst thinner-walled than endocyst, pale brown, and with a smooth surface bearing short, tapering processes that are scattered over the surface but are usually concentrated around the ambitus and horns. Paracingulum planar and having low marginal folds. Parasulcus is wide. Archeopyle is isodeltaform intercalary.

Dimensions. Holotype. Endocyst length, $52 \mu \mathrm{m}$; pericyst length, including processes, $63 \mu \mathrm{m}$. Range of endocyst length, $34(46.6) 60 \mu \mathrm{m}$; pericyst length, including processes, $43(59.5) 72 \mu \mathrm{m}$; process length about 2.5 to $8.0 \mu \mathrm{m}$. Twelve specimens were measured.

Description. Cysts are generally cornucavate, but the periphragm may be slightly separated at the lateral margins and occasionally small lateral horns may develop. Spine density is variable and midventral and middorsal areas are sometimes devoid of ornament. Spines are hollow, flattened, distally closed, occasionally bifid and may be clustered into small groups or lineations. They may have blunt or acuminate tips. Spines may be aligned on the paracingular margins. Low folds, which may bear aligned spines, have been observed occasionally on the epicyst and possibly represent similar parasutures to those which occur on the epicyst of Cristadinium cristatoserratum n. gen., n. sp. The archeopyle was rarely observed, although it appears to be isodeltaform hexa-intercalary with its lower margin possibly situated near the paracingulum.

Remarks. This species compares closely with Capillicysta fusca; the type species, described from the upper middle to upper Miocene of Japan (Matsuoka et al., 1987), differing mainly in its longer spine length (cf. 1.9 to $3.5 \mu \mathrm{m}$ for $C$. fusca); more prominent antapical horns; and apparently broader (steno-deltaform) archeopyle.

\author{
Genus CEREBROCYSTA Bujak, in Bujak et al., 1980 emend. \\ Stover and Williams, 1987 \\ Cerebrocysta? namocensis $\mathrm{n} . \mathrm{sp}$. \\ (Pl. 3; Figs. 10, 11; 18-22)
}

Holotype. Plate 3, Figures 10, 11. Sample 105-646B-67X, CC; (1)P15/0. 


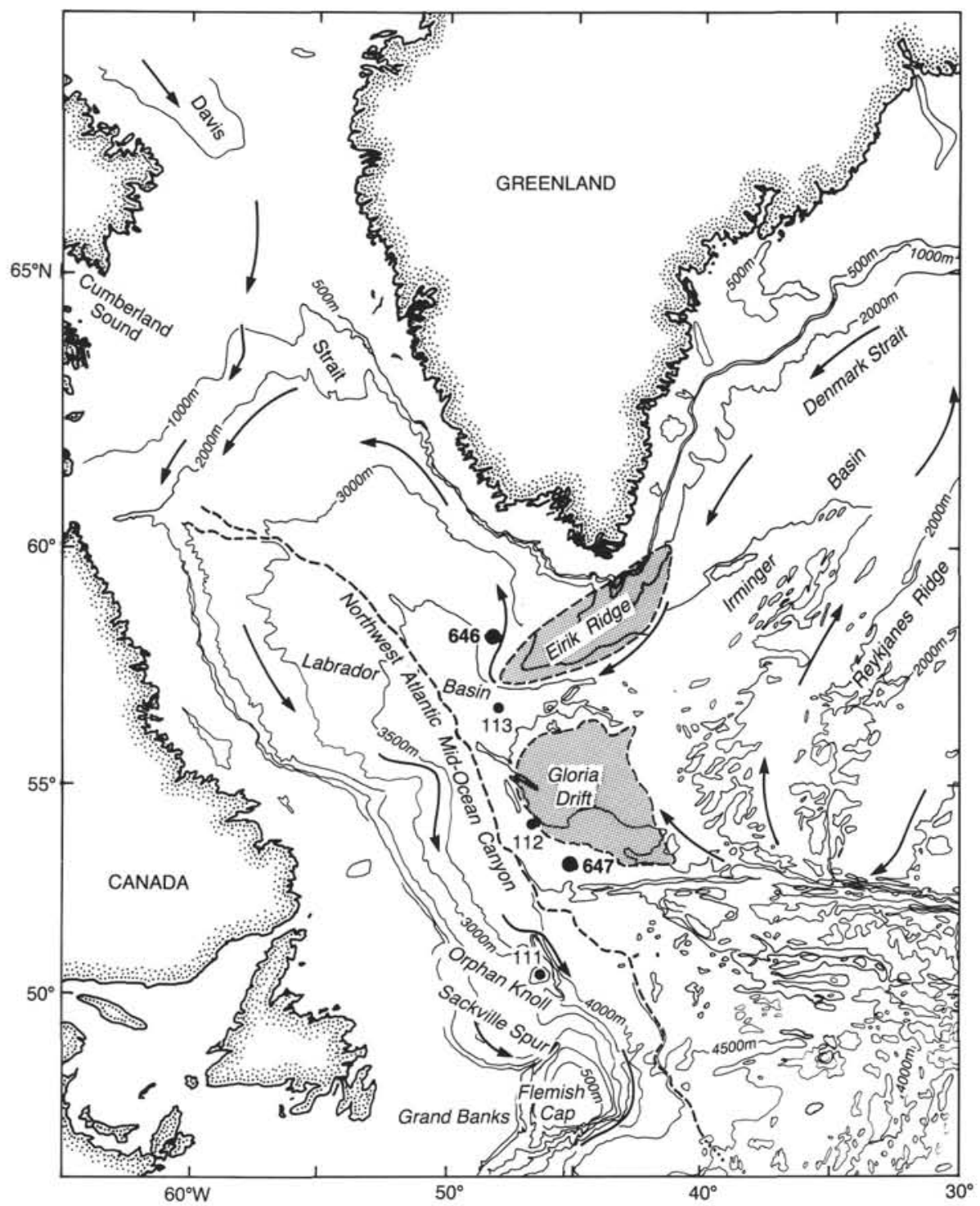

Figure 1. Location map of ODP Leg 105, Site 646 and other DSDP/ODP sites, showing bathymetry of the Labrador Sea and surrounding areas, together with the distribution of late Cenozoic drift deposits (shaded) and generalized modern bottom-water circulation (after McCave and Tucholke, 1986), as indicated by arrows.

Derivation of name. Named after NAMOC, an acronym for Northwest Atlantic Mid-Ocean Channel, a major submarine channel located near Site 646.

Diagnosis. Cysts autophragmal, spherical, proximate, with smooth surface and a network of low sinuous ridges forming a fine reticulate pattern. Ridges apparently do not reflect paratabulation except at the apex, where they may form a small circular to subpolygonal ring. Archeopyle Type $2 \mathrm{P}$; operculum free, probably compound.

Dimensions. Holotype: diameter, $46 \mu \mathrm{m}$. Range in diameter, 36(43.7)51 $\mu \mathrm{m}$. Wall thickness (including ridges), up to about $2 \mu \mathrm{m}$. Eighteen specimens were measured.

Description. Uncompressed cysts are spherical but may be folded into a broadly eliptical outline. Ridges are about $0.5-1.0 \mu \mathrm{m}$ high, rounded in transverse section and variably sinuous in plan view. Lacunae are irregularly polygonal and range from about 0.5 to about $3.0 \mu \mathrm{m}$ in maximum diameter. A variably pronounced apical ring structure of slightly thicker ridges was observed in four specimens, including the holotype (indicated by an arrow in Pl. 3, Fig. 11). The ring is subcircular to subpolygonal, of about 4.5-5.5 $\mu \mathrm{m}$ in diameter (based on five specimens); and encloses a small number of slightly thinner sinuous ridges. In two speci- mens (e.g., see Pl. 3, Fig. 22) there was observed within this apical ring, a concentric inner ring enclosing a central lacuna (reflecting an apical pore?) having a diameter of $1.5 \mu \mathrm{m}$. Archeopyle is precingular Type $2 \mathrm{P}$ (recognized in all specimens found), and possibly Type $2 \mathrm{P}_{3-4^{\prime \prime}}$, assuming a gonyaulacacean paratabulation and based on provisional interpretation of archeopyle shape in three specimens. Accessory sutures were not observed. Separated and detached opercular paraplates found within two cysts indicate a compound operculum.

Remarks. Many of the specimens recorded had undergone some degree of folding, and the apical ring structure observed in five specimens may have been obscured from view in other specimens. This structure possibly reflects the apical pore and/or preapical plate series of the thecate stage.

Discussion. The genus Cerebrocysta was erected for species with "an apparently random ornament of low crests" (Bujak, in Bujak et al., 1980 , p. 42) whereas in C.? namocensis n. sp., the ornament is more completely reticulated, for which reason it is provisionally assigned to this genus. Pyxidinopsis Habib, 1976 includes autophragmal species with low reticulate ornament, but this genus only accommodates species with a simple precingular archeopyle, compared to the Type $2 \mathrm{P}$ archeo- 
Table 1. Range chart showing stratigraphic distribution of species described in this paper for Hole 646B.

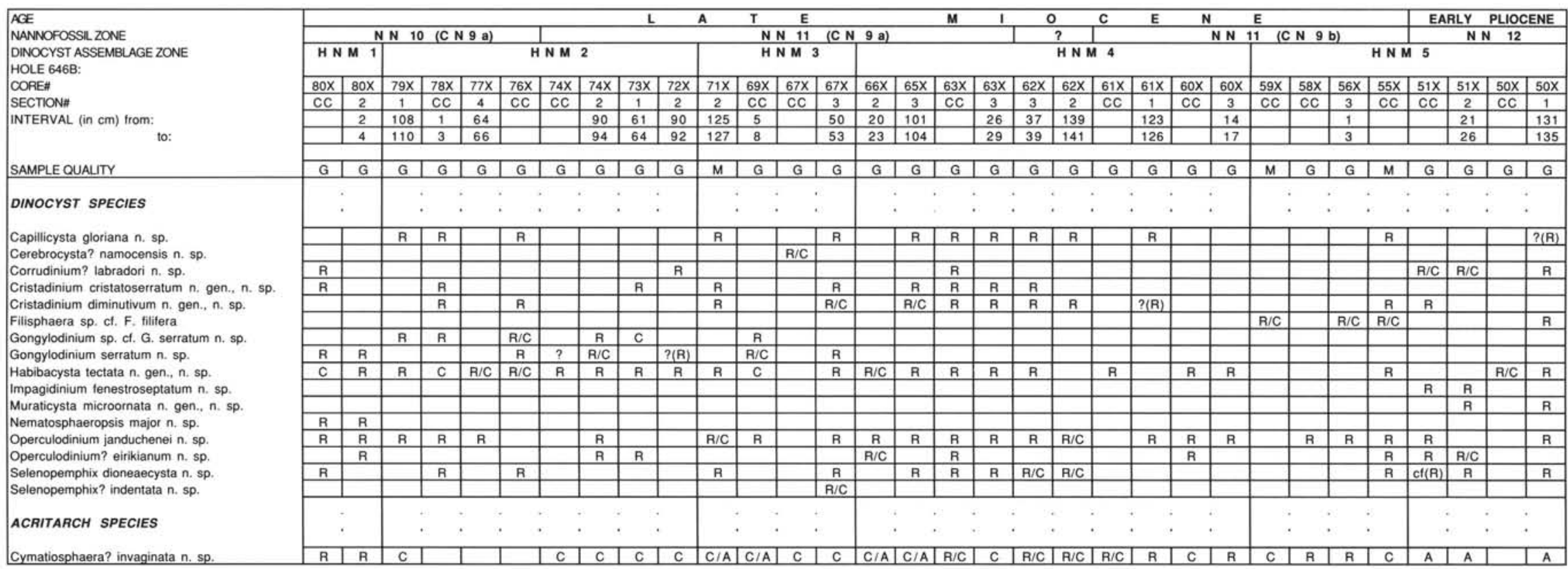

Note: Dinocyst assemblage zones (HNM1 through HNM5) are from Head et al. (a, this volume); nannofossil zones are from Knüttel et al. (this volume); and age is from the Leg 105 Shipboard Scientific Party (1987), using the geochronology of Berggren et al. (1985). $\mathrm{R}=$ rare; $\mathrm{C}=$ common; and $\mathrm{A}=$ abundant; these values record visual estimates of the abundance of taxa in each sample. Sample quality is indicated by $\mathrm{G}$ (good quality - no comtamination) and M (medium quality - probably slight contamination from drilling slurry). 
pyle of $C$. ? namocensis $\mathrm{n}$. sp. Muraticysta $\mathrm{n}$. gen. has radiating, thin, delicate, nontabular muri, which arise from a reticulate base (this chapter), compared to the low ridges of $C$. ? namocensis $\mathrm{n}$. $\mathrm{sp}$.

\section{Genus CORRUDINIUM Stover and Evitt, 1978. \\ Corrudinium? labradori $\mathrm{n} . \mathrm{sp}$. \\ (Pl. 3; Figs. 1-8, 12)}

Holotype. Plate 3, Figures 1-3, 5-6. Sample 105-646B-51X-2; 21-26 $\mathrm{cm}$; (1) $041 / 3$.

Derivation of name. From the name Labrador, with reference to the Labrador Sea, where Site 646 is located.

Diagnosis. Cysts small, spherical, proximate, and autophragmal. Surface smooth, with a fine network of narrow sinuous crests that form a nearly complete reticulum. Paratabulation presumably gonyaulacacean and weakly reflected by the presence of certain more prominent crests, which may be slightly broader, higher, and/or straighter than others. Archeopyle precingular Type $2 \mathrm{P}$, operculum free, probably compound.

Dimensions. Holotype: Cyst diameter, including crests, $27 \mu \mathrm{m}$. Range in cyst diameter, including crests, $25(27.9) 31 \mu \mathrm{m}$. Maximum diameter of lacunae up to about 2.5 to $3.0 \mu \mathrm{m}$. Crest height about 1.0 to $1.5 \mu \mathrm{m}$. Sixteen specimens were measured.

Description. Cysts are small with a delicate and fine reticulate ornament. Crest tops are parallel to cyst surface or are slightly undulate. Paratabulation may be partially and incompletely expressed by more prominent parasutural crests. Such traces of paratabulation were seen in $75 \%$ of the specimens found. The paracingulum was recognized on some specimens, as was a large paraplate on the hypocyst, interpreted to represent a single antapical paraplate. For each of the 10 specimens in which the archeopyle style could be determined, a Type 2P archeopyle with free operculum was observed. The operculum appears to be compound, based on a single separated and detached opercular paraplate found within one cyst. Specific precingular paraplates involved in archeopyle formation could not be determined with certainty, although these might be paraplates $2^{\prime \prime}$ and $3^{\prime \prime}$ for the specimen illustrated in Plate 3, Figure 9.

Discussion. Both Corrudinium harlandii Matsuoka, 1983, from the Pliocene to lower Pleistocene of Japan, and "?Ellipsodinium sp." of Harland, 1979 (synonymized with Corrudinium harlandii by Matsuoka, 1983) from the lower Pliocene of the Bay of Biscay, differ from C.? labradori $\mathrm{n}$. sp. in their larger sizes ( $40-53 \mu \mathrm{m}$ for $C$. harlandii; $36 \mu \mathrm{m}$ for ?Ellipsodinium $\mathrm{sp}$.), in having less fine reticulate ornament that more completely expresses paratabulation and in apparently possessing a Type $\mathrm{P}$ precingular archeopyle. C.? labradori $\mathrm{n}$. sp. was provisionally assigned to Corrudinium owing to its possession of a Type $2 \mathrm{P}$ archeopyle.

\section{Genus CRISTADINIUM n. gen.}

Derivaton of name. Latin, crista, crest; with reference to the development of epicystal parasutural crests.

Type species. Cristadinium cristatoserratum n. gen., n. sp., upper Miocene and lower Pliocene of the Labrador Sea.

Diagnosis. Cysts autophragmal or possibly with closely appressed wall layers, dorso-ventrally compressed, brown, peridinioid outline and having an apical and two antapical horns. Paracingulum planar to weakly helicoidal with margins bearing relatively continuous crests. Relatively continuous parasutural crests are present on the epicyst where they may incompletely reflect paratabulation. No other ornament occurs on the epicyst. The hypocyst may be without ornament or may bear crests and/ or scattered projections. Wall surface smooth to finely granulate. Archeopyle presumably hexa-intercalary involving paraplate $2 \mathrm{a}$. Paratabulation probably peridinioid.

Remarks. Relatively continuous parasutural crests, which may be straight-topped or surmounted by various ornament, are a characteristic feature of this genus. Other species presently assigned to this genus (i.e., Cristadinium diminutivum $\mathrm{n}$. $\mathrm{sp}$. of this study and Cristadinium $\mathrm{sp} .1$ and Cristadinium sp. 2 of Head et al., c, this volume) suggest that a variety of crest types may be embraced within this genus. Gerlachidium Benedek and Sarjeant, 1981 differs explicitly from Cristadinium by possessing structures on the epicyst that do not form continuous parasutural crests (Benedek and Sarjeant, 1981, p. 340).

\section{Cristadinium cristatoserratum n. gen., n. sp.}

$$
\text { (Pl. 1, Figs. 9-11, 13-15) }
$$

Holotype: Plate 1, Figures 10-11; Sample 105-646B-80X, CC; (2)U $22 / 2$.
Derivation of name. Latin, crista; crest, and serratus; serrated, toothed, with reference to the epicystal ornament.

Diagnosis. Cysts dorsoventrally compressed, proximate, autophragmal with peridinoid outline and having an apical and two antapical horns. Cysts are pale to dark brown in color. Epicyst and hypocyst of approximately equal length. Antapical horns of equal length with solid acuminate tips. Wall thin, smooth to faintly granulate. Scattered small solid spines that may show linear arrangement are present on the hypocyst. The paracingulum is planar to weakly helicoidal and is continuous on the dorsal surface but separated ventrally by a wide unornamented sulcal region. Paracingular margins bear serrated or denticulate crests. Epicyst devoid of scattered spines although bearing two pairs of serrated or denticulate crests (one ventral and one lateral pair) that occur along most of the length of the epicyst and converge toward the apex. The archeopyle was not seen, the operculum apparently being in place in most specimens observed.

Dimensions. Holotype: length, $44 \mu \mathrm{m}$. Range in cyst length, 33(42.3) $54 \mu \mathrm{m}$. Twelve specimens were measured.

Description. Sparsely scattered small solid spines (up to about 1.5 $\mu \mathrm{m}$ long) occur on the hypocyst, particularly on the antapical horns. Spines may have acuminate or truncated tips and commonly occur in short linear to arcuate groups, incompletely reflecting hypocyst tabulation. The paracingular margins have crests about $2 \mu \mathrm{m}$ high. The epicyst is devoid of scattered spines. Two pairs of parasutural crests (one pair on each side of the wide parasulcal region and one pair on the lateral margins) occur along most of the length of the epicyst and converge toward the apex. These crests are up to about $3 \mu \mathrm{m}$ high and are distally serrated or denticulate. Additional short crests were sometimes observed at the apex (see Pl. 1; Figs. 14, 15). Seventeen of the 18 specimens found were dorsoventrally compressed.

Discussion. Gerlachidium aechmophorum (Benedek, 1972) Benedek and Sarjeant, 1981 emend. Benedek and Sarjeant, 1981, described from the Oligocene of Germany, differs in having parasutural crests that are discontinuous both on the paracingular margins and on the epicyst, and that are higher $(8-12 \mu \mathrm{m})$ and less evenly serrated than for $C$. cristatoserratum n. gen., n. sp.

Cristadinium aff. cristatoserratum, Cristadinium sp. 1 and Cristadinium sp. 2, all recorded by Head et al. (c, this volume) from the Miocene of Baffin Bay, differ from C. cristatoserratum in various details as follows. $C$. aff. cristatoserratum has crests on both the epicyst and hypocyst, which in places are finely indented rather than serrated. $C . \mathrm{sp} .1$ is characterized by prominent parasutural crests on both the epicyst and hypocyst, which have indented distal margins. $C$. sp. 2 differs in the absence of serrated or denticulate ornament on the hypocyst.

Occurrences. C. cristatoserratum is presently known from the middle or late Miocene of Baffin Bay (Head et al., c, this volume) and late Miocene of the Labrador Sea (this chapter).

Cristadinium diminutivum n. gen., n. sp.

(Pl. 1; Figs. 8, 12, 16; Pl. 2, Figs. 8, 9)

Holotype. Plate 1, Figure 8, Sample 105-646B-65X-3, 101-104 cm; (1)F32/0.

Derivation of name. Latin diminutivus, diminutive; referring to the small size of the cyst.

Diagnosis. Cysts small, proximate, autophragmal, dorsoventrally compressed and brown in color. Cyst length greater than width. Epicyst triangular and straight sided. Apical horn pointed (except at tip) and hollow. Hypocyst of equal length to, or slightly shorter than epicyst, with moderately to strongly convergent lateral margins, and having two antapical horns of equal length, which are slightly divergent to parallel and taper to acuminate solid tips. Lateral sides of hypocyst normally straight to slightly concave, but may be slightly convex. Wall surface granulate, with granules showing some longitudinal alignment. Very thin low crests with distinctively thickened bases occur along lateral margins of epicyst and hypocyst. Paracingulum planar, often indicated by one or more folds, and bearing a single crest similar to that of lateral margins. Archeopyle isodeltaform hexa-intercalary, involving paraplate $2 \mathrm{a}$ only, Operculum, free or possibly adherent.

Dimensions. Holotype: Cyst length, $45 \mu \mathrm{m}$. Range in cyst length, 28(41.0)54 $\mu \mathrm{m}$. Crest height $0.5-1.5 \mu \mathrm{m}$. Twenty-eight specimens were measured.

Description. Cysts have an angular outline with straight sides, except for the antapical margin separating the antapical horns, which varies from weakly to strongly concave. All specimens recorded were dorsoventrally compressed. Crests occur along the lateral margins of epicyst 
and hypocyst and occupy most of the epicystal lateral margins and a variable proportion of the hypocystal lateral margins (generally the lower two thirds, as for the holotype, Pl. 1, Fig. 8, and for the specimen illustrated in Pl. 1, Fig. 16). Crest bases form narrow but conspicuous thickenings and from these rise low, very thin and diaphanous crests of apparently even height. The paracingulum is indicated by a fold that may extend some distance above or below the equatorial line and that bears a single crest similar to those occuring on lateral margins. One or two narrow meridional folds were sometimes observed on the epicyst. Faint and discontinuous lines were occasionally observed on the hypocyst and may represent paratabulation. The operculum was found to be in place in most specimens (possibly adherent), although it was free in occasional specimens. The principal archeopyle suture is entire.

Discussion. This species is characterized by a combination of small size, narrow, angular outline, and low thin crests on lateral margins of epicyst and hypocyst.

Genus FILISPHAERA Bujak, 1984

Filisphaera? sp. cf. F. filifera Bujak, 1984

(Pl. 5, Figs. 7, 9)

Discussion. F.? sp. cf. F. filifera is fully described in Head et al. (a, this volume) and is included here for comparison with Muraticysta microornata n. gen., n. sp., from which it differs in having finer (less than $1 \mu \mathrm{m})$ periphragm details.

F. filifera is stated to have an outer wall composed of radiating fibers (Bujak, 1984, p. 185). The present taxon bears superficial resemblance to $F$. filifera, having a thick and seemingly radially fibrous periphragm as observed in optical section under bright field. In surface view, however, the periphragm appears microreticulate (PI. 5, Fig. 9), although its details approach the resolving limits of light microscopy. Thus, the structural nature of the periphragm may possibly be finely reticulate rather than radially fibrous, although this will require verification using SEM. Because of this uncertainty, its identification is provisional.

\section{Genus GONGYLODINIUM Fenton et al., 1980}

Discussion. Fenton et al. (1980) erected Gongylodinium for proximate, autophragmal, and spheroidal to ovoidal cysts having a precingular Type $2 \mathrm{P}$ archeopyle and free operculum. Both paraplates involved in archeopyle formation were stated to be trapezoidal (Fenton et al., 1980, p. 158), although one of these (paraplate $3^{\prime \prime}$ ) may be pentagonal if a gonyaulacacean paratabulation involving paraplates $2^{\prime \prime}$ and $3^{\prime \prime}$ or $3^{\prime \prime}$ and $4^{\prime \prime}$ in the operculum, is assumed (see Stover and Williams, 1987, Fig. 39). According to Fenton et al. (1980, p. 158), Gongylodinium differs from Bitectatodinium Wilson, 1973 in possessing larger opercular paraplates and a simpler nontectate wall structure. Bitectatodinium is a monotypic genus (type species, B. tepikiense) described from the middle Pleistocene of New Zealand. Gongylodinium was erected for two species ( $G$. erymnoteichos, the type, and $G$. hocneratum), both from the Middle Jurassic of England. Gongylodinium has not previously been recorded outside the Jurassic (Stover and Williams, 1987, 115).

\section{Gongylodinium serratum $\mathrm{n} . \mathrm{sp}$.}

$$
\text { (Pl. 3, Figs. 14-16) }
$$

Holotype. Plate 3, Figures 14-16; Sample 105-646B-80X-2, 2-4 cm; (1) $\mathrm{H} 35 / 2$.

Derivation of name. Latin serratus, with reference to the finely serrated archeopyle margin of this species.

Diagnosis. Cyst proximate, autophragmal, and spherical. Surface nearly smooth or faintly granulate to faintly granulorugulose. Archeopyle precingular Type $2 \mathrm{P}$, operculum free, probably compound. Principal archeopyle suture, angular and with finely serrated margins. There is no other expression of paratabulation.

Dimensions. Holotype: maximum diameter, $40 \mu \mathrm{m}$. Range in maximum diameter, 34(42.5)49 $\mu \mathrm{m}$ (based on relatively uncompressed cysts). Wall thickness, up to $1.2 \mu \mathrm{m}$. Thirteen specimens were measured.

Description. Uncompressed cysts are spherical but may be folded into a broadly eliptical outline. The principal archeopyle suture is angular and has distinctively serrated archeopyle margins. The adapical margin of the archeopyle may be irregular, particularly in thinner walled (i.e., $0.5 \mu \mathrm{m}$ or less) specimens. Accessory sutures were not identified with certainty. The operculum is free and compound (indicated by separated opercular pieces, observed within two cysts). Observed opercular pieces have serrated margins. We were unable to determine specific precingular paraplates involved in archeopyle formation because of the somewhat irregular adapical archeopyle margin.

Discussion. The serrated archeopyle margin of this species distinguished it from all other species of Gongylodinium (however, see also $G$. sp. cf. G. serratum, this chapter).

Gongylodinium sp. cf. G. serratum n. sp. (Pl. 3, Figs. 13, 17)

? Bitectatodinium tepikiense Wilson, 1973; Piasecki, 1980, Pl. 3, Fig. 1.

Dimensions. Range in maximum diameter, $42(46.5) 50 \mu \mathrm{m}$ (based on relatively uncompressed cysts). Wall thickness, up to $1.0 \mu \mathrm{m}$. Nine specimens were measured.

Description. Cysts are proximate, autophragmal, and spherical but may be folded into a broadly eliptical outline. Surface nearly smooth or faintly granulate to faintly granulorugulose. Archeopyle precingular Type $2 \mathrm{P}$, operculum free, probably compound. Principal archeopyle suture, angular and may have an irregular, torn appearance along the adapical margin. Accessory sutures were not identified with certainty. The operculum is free. We were unable to determine specific precingular paraplates involved in archeopyle formation. There is no other expression of paratabulation.

Discussion. This species differs from G. serratum n. sp. in having an archeopyle with straight or irregular, rather than serrated, margins. However, intermediate forms possessing a very finely serrated archeopyle margin were also observed. From a total of 38 specimens assigned to either $G$. serratum or $G$. sp. cf. $G$. serratum, in which the archeopyle was seen, 18 were found to have distinctively serrated archeopyle margins (and thus were assigned to G. serratum), the remainder have straight or slightly serrated margins in approximately equal proportions and were assigned to $G$. sp. cf. $G$. serratum.

A specimen illustrated as Bitectatodinium tepikiense by Piasecki, 1980 from the Miocene of Denmark is apparently autophragmal with a fairly smooth surface. This specimen may be assignable to $G$. sp. cf. $G$. serratum, although it has a larger diameter $(86 \mu \mathrm{m}$, measured from illustration). A specimen attributed to $B$. tepikiense by Powell (1986, Pl. 5, Fig. 3 for SEM illustration) from the middle Miocene of northwest Italy differs from $G$. sp. cf. $G$. serratum in having a finely reticulate surface. Gongylodinium hocnerum Fenton et al., 1980 from the Middle Jurassic of England differs in occasionally possessing a paracingulum and parasulcus.

\section{Genus HABIBACYSTA n. gen.}

Derivation of name. Named in tribute to American palynologist, Daniel Habib, in recognition of his palynological contribution to the Deep Sea Drilling Project, and from the Latin cysta, cyst or cell.

Type species. Habibacysta tectata n. gen., n. sp., late Miocene, Labrador Sea.

Diagnosis. Cysts spherical to subspherical, holocavate, of small to medium size having a wall composed of a solid endophragm, a columellate periphragm, and a thin ectophragm that is attached to the columellae and may be continuous or discontinuous. Archeopyle precingular Type $\mathrm{P}$, formed by loss of paraplate $3^{\prime \prime}$. Other paratabular features weakly, or not indicated.

Remarks. The periphragm consists of small solid rods or granules that are attached to both endophragm and periphragm. The wall may appear granulate in plan view. There may be partial fusion between adjacent rods to form discontinuous ridges beneath the ectophragm.

Discussion. A characteristic feature of this genus is its three-layered wall structure. Tectatodinium differs from Habibacysta n. gen. in having a bilayered wall with an outer spongy fibrous layer. Filisphaera Bujak, 1984 differs also by having a bilayered wall and does not possess an ectophragm.

Note on terminology. For convenience in descriptions, we use the term periphragm for the columellate layer to distinguish it from the innermost wall layer (endophragm) from which it rises. The outermost layer is the ectophragm. The recognition of two inner wall layers is based on relief, rather than microstructure, and the term autophragm 
might alternatively be applied to these. The term ectophragm, however, remains unchanged.

\section{Habibacysta tectata n. gen., n. sp.}

$$
\text { (Pl. 4, Figs. 1-6, 9, 10) }
$$

? Tectatodinium sp. B Wrenn amd Kokinos, 1986, Pl. 5, Figs. 7-9, Pl. 18, Fig. 6.

Dinocyst sp. 1. Mudie, in press, Pl. 5, Figs. 4, 8.

Derivation of name. Latin tectum, roof, cover, with reference to the outer membrane of the cyst wall.

Holotype. Plate 4, Figures 1, 2, 5, 6. Sample 105-646B-69X, CC $(5-8 \mathrm{~cm}) ;(2) \mathrm{S} 42 / 4$.

Diagnosis. Cysts spherical, holocavate. Endophragm, thin and solid, bearing rods or granules (periphragm) that may be separate or adjacently fused. Ectophragm supported by the rods/granules is smooth and extremely thin and is commonly irregularly perforate or forms a delicate irregular reticulation (see Pl. 4, Fig. 4), although it appears to be entire in some specimens. Archeopyle precingular formed by loss of paraplate $3^{\prime \prime}$. Operculum free. There is no other expression of paratabulation.

Dimensions. Holotype: cyst diameter, $33 \mu \mathrm{m}$. Range in cyst diameter, 29(36) $45 \mu \mathrm{m}$. Total wall thickness, around 1 to $2 \mu \mathrm{m}$. Fifteen specimens were measured.

Description. The ectophragm, especially in specimens where it is discontinuous, may only be detected under oil immersion by careful observation of optical sections of the cyst wall. Such observation suggests that the ectophragm may be entire in some specimens. Fine details of the ectophragm surface can only be observed with SEM. Plate 4, Figure 4 shows a discontinuous network of narrow irregular platforms (see also Wrenn and Kokinos, 1986, Pl. 18, Fig. 6).

Discussion. This species has been recorded from the middle Miocene to lower upper Pleistocene of the Norwegian Sea (as Dinocyst sp. 1 in Mudie, in press), from the middle and lower upper? Miocene of Baffin Bay (Head et al., c, this volume). It appears similar to Tectatodinium sp. B of Wrenn and Kokinos, 1986, recorded from the middle or upper Miocene to Pliocene of the Gulf of Mexico. Specimens illustrated using SEM and assigned to Tectatodinium sp. B (Wrenn and Kokinos, 1986, Pl. 18, Fig. 6), and to $H$. tectata (this study, Pl. 4, Fig. 4) are closely comparable, although the ectophragm is slightly less continuous on the specimen referred to $H$. tectata.

\section{Genus IMPAGIDINIUM Stover and Evitt, 1978}

Impagidinium fenestroseptatum $\mathrm{n} . \mathrm{sp}$.

(Pl. 2, Figs. 5-7, 10-14)

Holotype. Plate 2, Figures 11-13; Sample 105-646B-51X-2, 21-26 $\mathrm{cm}$; (2)N34/0.

Derivation of name. Latin fenestra, window, and septum, partition; with reference to the fenestrate parasutural crests.

Diagnosis. Cysts proximochorate with spherical to subspherical outline. Central body smooth and thin walled. Parasutural crests robust and of constant height and suggest a gonyaulacacean tabulation. Oval fenestrations are developed in the crests and may be restricted to the distal half. Crest thickness may increase distally, and the crest top is T-shaped in cross section so as to form a narrow platform, the margins of which are irregular and sinuous in plan view. Paratabulation not determined precisely but appears similar to the genus Impagidinium. Archeopyle type not determined, although presumably precingular Type P.

Dimensions. Holotype: maximum overall diameter (i.e., including crests), $65 \mu \mathrm{m}$. Range of maximum overall diameter, 52(58)65 $\mu \mathrm{m}$. Crest height about 6 to $10 \mu \mathrm{m}$; distal crest platform about 2 to $3 \mu \mathrm{m}$ wide. Eleven specimens were measured.

Remarks. In many specimens the wall of the central body was not present, which resulted in a skeletal structure formed by the parasutural crests. In other specimens, the body wall was present but extremely thin, despite the well-preserved state of the assemblage as a whole. Consequently, the archeopyle was not recognized. The extremely thin central body of $I$. fenestroseptatum is presumably a primary feature.

Discussion. In I. fenestroseptatum n. sp., parasutural crests are fenestrate, whereas in both $I$. grandis (Davey, 1975) Jan du Chêne et al., 1986 (from the Senonian) and I. aquaeductum (Piasecki, 1980) Lentin and Williams, 1985 (from the Miocene), crest tops are supported by rows of more discretely formed processes. Pterodinium babatum Below,
1981 (0.C.*, pro. Pterodinium bab Below, 1981), described from the Lower Cretaceous of Morocco, lacks distal crest platforms and has a more angular outline than I. fenestroseptatum $\mathrm{n}$. sp.

$$
\text { Genus MURATICYSTA n. gen., n. sp. }
$$

Derivation of name. Latin murus, wall, and cysta, cyst; with reference to the thick, finely reticulate nature of the outer wall layer of the cyst.

Type species. Muraticysta microornata n. gen., n. sp.

Diagnosis. Cysts proximate to proximochorate, spherical to ovoidal. Cyst wall composed of two closely appressed layers: a thin solid endophragm and a thicker periphragm of radiating, thin, delicate, nontabular muri, which arise from a reticulate base. Other projections are absent. Archeopyle precingular.

Remarks. Muraticysta is principally intended for species with a Type $\mathrm{P}_{3}$, precingular archeopyle, as in the type species, but may possibly include specimens in which up to three precingular paraplates are involved in archeopyle formation. This genus may accommodate species with a slight apical lobe.

Discussion. Filisphaera Bujak, 1984 has a periphragm composed of "radiating fibers" (Bujak, 1984, p. 185), compared to the thick, finely reticulate periphragm of Muraticysta. Cerebrocysta Bujak in Bujak et al., 1980 emend. Stover and Williams, 1987 differs by being autophragmal and having low, discontinuous, sinuous ridges, rather than a reticulate network of narrow crests. Tectatodinium Wall, 1967 differs in having an outer wall that we interpret as mainly cancellous to fibroid, in which the structure is generally not radially aligned.

\section{Muraticysta microornata n. gen., n. sp.}

$$
\text { (Pl. 5, Figs. 1-3, 5-7) }
$$

Holotype. Plate 5, Figures 1-3, 5, Sample 105-646B-51X-2, 21-26 $\mathrm{cm}$; (1)G20/0.

Derivation of name. Latin micro, small, ornatum, ornamented; with reference to the finely reticulate periphragm of the cyst wall.

Diagnosis. Cysts spherical to ovoidal with a closely appressed biphragmal wall. Endophragm thinner than periphragm, which forms a smooth reticulate ornament of fine, delicate sinuous muri 2-3 $\mu \mathrm{m}$ high that have slightly undulating crest tops. Lacunae have an irregular polygonal outline and are about 1.5-3.5 $\mu \mathrm{m}$ wide. Archeopyle precingular Type $\mathrm{P}$ (presumably Type $\mathrm{P}_{3^{*}}$ ) and large. Operculum free. There is no other indication of paratabulation.

Dimensions. Holotype: maximum diameter, $57 \mu \mathrm{m}$. Range of maximum diameter, 53(58)62 $\mu \mathrm{m}$; muri $2-3 \mu \mathrm{m}$ high and 0.2-0.5 $\mu \mathrm{m}$ wide. Nine specimens were measured.

Remarks. In all specimens where the archeopyle could be recognized, Type $\mathbf{P}$ was observed.

Discussion. This species is similar in size and shape to Filisphara filifera Bujak, 1984 and differs in having a finely reticulate periphragm, compared to the radially fibrous periphragm of F. filifera (Bujak, 1984, p. 185). However, these two species may appear similar under low magnification (see also discussion of $F$.? sp. cf. F. filifera, this chapter). $F$. filifera may also possess a small apical lobe, and the archeopyle may involve the loss of one or two precingular paraplates. It was not possible to determine whether a slight apical lobe is present in $M$. microornata $\mathrm{n}$. sp. because of the folded condition of most specimens encountered.

\section{Genus NEMATOSPHAEROPSIS Deflandre and Cookson, 1955} emend. Williams and Downie, 1966

Discussion. This genus was considered by Stover and Evitt (1978) to differ from Cannosphaeropsis in having adjacent processes linked distally by "at least two trabeculae," as compared with single trabeculae for Cannosphaeropsis (Stover and Evitt, 1978, p. 143). While accepting that paired trabeculae may be a feature worthy of generic distinction, we note that neither the original nor emended diagnoses of Nematosphae-

*The specific epithet of Pterodinium bab Below, 1981 ("bab," from the arabic for "door," referring to the development of the parasutures-Below, 1981, p. 113) was not latinized in accordance with Principle V of the ICBN. Thus, it is treated here as an orthographic error (ICBN, Article 73.10) and corrected to Pterodinium babatum Below, 1981. 
ropsis specify this configuration of trabeculae, and thus as presently emended, no clear distinction exists between Nematosphaeropsis and Cannosphaeropsis. The genus Nematosphaeropsis is currently under revision by J. H. Wrenn (pers. comm. to M.J.H., 1987).

\section{Nematosphaeropsis major n. sp.}

$$
\text { (Pl. 2, Figs. 1-4) }
$$

Holotype. Plate 2, Figures 1, 2; Sample 105-646B-80X-2, 2-4 cm; (1) Q13/1.

Derivation of name. Latin major, with respect to the large size of this species.

Diagnosis. Cysts large, chorate and trabeculate with spherical to subspherical central body and hollow processes that are distally trifurcate (and bifurcate?); each branch supports a pair of narrow, parallel, ribbonlike trabeculae. Wall surface is almost smooth to faintly granulate. Archeopyle precingular Type $\mathrm{P}$ (presumably Type $\mathrm{P}_{3^{*}}$ ). Operculum free.

Dimensions. Holotype: central body maximum diameter, $50 \mu \mathrm{m}$; overall diameter, $87 \mu \mathrm{m}$. Range, maximum central body diameter, 44(50.9)63 $\mu \mathrm{m}$, overall diameter, 74(81.7)91 $\mu \mathrm{m}$. Width of trabeculae, $1.0-2.5 \mu \mathrm{m}$. Twelve specimens were measured.

Description. Processes are gonal and possibly intergonal. Paratabulation could not be determined, owing to compression of specimens, although appears to be gonyaulacacean and typical for the genus Nematosphaeropsis. The wall surface is commonly faintly granulate. The granules are slightly raised, usually discrete, rounded cushions of $1 \mu \mathrm{m}$ or less in diameter; this morphology is best observed under interference contrast microscopy. The archeopyle is precingular and presumably formed by detachment of paraplate $3^{\prime \prime}$.

Discussion. This species is distinguished by its large size and narrow ribbonlike trabeculae. $N$. lemniscata Bujak, 1984 is much smaller, with an apparently denser network of trabeculae (presumably due to a greater number of intergonal processes). Both species were present in the same samples and could be readily differentiated. $N$. downii Brown, 1986 is similar in size and possibly also in body surface ornament. It differs (1) in having broader trabeculae, which occur as parallel pairs "linked by a thin membrane" (Brown, 1986, p. 7); and (2) in the occasional presence of parasutural features on the cyst wall, which were not observed for $N$. major n. sp.

\section{Genus OPERCULODINIUM Wall, 1967 \\ Operculodinium? eirikianum n. sp. (Pl. 4, Figs. 11, 13-16)}

Holotype. Plate 4, Figures 11, 15, 16. Sample 105-646B-66X-2, $20-23 \mathrm{~cm}$; (1) V $15 / 4$.

Derivation of name. Named after the Eirik Ridge, Labrador Sea, on the northwestern flank of which Hole 646B was drilled.

Diagnosis. Cysts skolochorate, having a spherical body and nontabular processes. Cyst wall apparently single layered; solid and nonfibrous and has a prominently microreticulate surface. Processes are solid, circular in cross section, nonfibrous and taper gradually to an acuminate tip. They are often sinuous toward the tips and may have scattered fine granules over their surface. Archeopyle precingular Type P (presumably by loss of paraplate $3^{\prime \prime}$ ). Operculum free.

Dimensions. Holotype, body diameter, $34 \mu \mathrm{m}$, process length, 8-9 $\mu \mathrm{m}$. Range in diameter, $33(35.0) 42 \mu \mathrm{m}$. Range in process length, $5(8) 10$ $\mu \mathrm{m}$. Wall thickness up to $1.5 \mu \mathrm{m}$, but usually $1 \mu \mathrm{m}$ or less. Seventeen specimens were measured.

Remarks. A distinctive feature of this species is its microreticulate wall surface. Muri width and diameters of lacunae are of approximately equal size (a few tenths of a micrometer) and provide a regular surface pattern that displays a prominent LO-effect. The surface may appear finely "granulate" but LO-analysis (see Erdtman, 1969, p. 46, 47) using bright field microscopy suggests that the surface is microreticulate. The surface appears finely punctate under interference contrast microscopy.

Discussion. The long acuminate solid, nonfibrous processes and nonfibrous microreticulate surface distinguish this species from "typical" Operculodinium taxa, including the type species. These characters possibly reflect a fundamentally different structural pattern between $0 . ?$ eirikianum and typical species of Operculodinium.
O. longispinigerum Matsuoka, 1983 from the Miocene of Japan, has a smooth to granulate wall surface, rather than a microreticulate wall surface, as found in $O . ?$ eirikianum n. sp. Both $O$. echigoense Matsuoka, 1983 and $O$. walli Matsuoka, 1983 have capitate or bifid process terminations, compared to the tapering, acuminate process terminations of $O$. ? eirikianum $\mathrm{n}$. sp.

\section{Operculodinium janduchenei $\mathrm{n} . \mathrm{sp}$.}

$$
\text { (Pl. 4, Figs. 7, 8, 12) }
$$

Operculodinium sp. Jan du Chêne, 1977, p. 106, Pl. 1, Figs. 7, 8. Operculodinium sp. of Jan du Chêne; Edwards, 1984, p. 587, Pl. 2, Figs. 3a, 3b.

Operculodinium sp. of Jan du Chêne; Wrenn and Kokinos, 1986, Pl. 8, Figs. 4, 7; Pl. 18, Fig. 5.

Operculodinium sp. of Jan du Chêne (1977); Mudie, 1987, p. 805, Pl. 2, Figs. $11 \mathrm{a}, 11 \mathrm{~b}$, and $12 \mathrm{a}$ ? and $12 \mathrm{~b}$ ?

Operculodinium sp. du Chêne; Mudie (in press), Tables for Hole 642A, 642B, 642C, and 643A.

Holotype. Plate 4, Figures 7, 8. Sample 105-646B-78X, CC (1-3 $\mathrm{cm})$; (6) F $47 / 2$.

Derivation of name. Named in tribute to the palynologist, Roger Jan du Chêne.

Diagnosis. Cysts small, proximochorate, with subspherical or broadly ellipsoidal body having a granulate wall surface. Processes are short conical and hollow, and may be distally closed or truncated and open. Distribution is apparently nontabular. Archeopyle precingular Type $\mathrm{P}$ (presumably Type $\mathrm{P}_{3^{*}}$ ). Operculum free. There is no other indication of paratabulation.

Dimensions. Holotype, maximum diameter (excluding processes), $32 \mu \mathrm{m}$. Range of maximum diameter, 27(31)38 $\mu \mathrm{m}$. Eleven specimens were measured.

Description. Wall surface varies from coarsely to faintly granulate, and some specimens may have short, solid, conical granules interspersed between processes, as described by Mudie $(1987$, p. 805$)$. Processes are variable but most are open distally, although some specimens were observed with predominantly distally closed processes, and often specimens were found to possess a range of process morphologies. On the holotype, most processes are distally open, although some appear to be closed distally. Processes have a fairly regular distribution and appear to be nontabular. The archeopyle is presumably formed by loss of paraplate $3^{\prime \prime}$.

Discussion. This species was first described and illustrated by Jan du Chêne (1977) from the upper Miocene of Spain and has subsequently been recorded from the North Atlantic (Edwards, 1984; Mudie, 1987), Norwegian Sea (Mudie, in press), and Gulf of Mexico (Wrenn and Kokinos,1986). Operculodinium sp. of Harland, 1979, from the Bay of Biscay, may also belong to this species. $O$. janduchenei $\mathrm{n}$. sp. has a recorded range of lower upper Miocene (see discussion in Head et al., a, this volume) to upper Pliocene (Mudie, 1987 and in press) and appears to be an outer neritic to oceanic species, according to its recorded distribution and from the present study. Its geographic distribution is discussed in Head et al. (a, this volume). Specimens illustrated by Edwards (1984) and Jan du Chêne (1977) at diameters of $50 \mu \mathrm{m}$ and $45 \mu \mathrm{m}$, respectively, are larger than those recorded by Mudie (1986) and this study.

Specimens recorded by Mudie (1987) as Operculodinium sp. of Piasecki (1980) and Operculodinium sp. of Jan du Chêne (1977) illustrated in Pl. 2, Figs. 11a, 11b, 12b, respectively) from the upper Miocene and Pliocene of DSDP Sites 611 (northern North Atlantic) and 607 (centeral North Atlantic), will require restudy, in view of current understanding of the morphology of these and similar taxa (P.J.M., unpublished data).

Genus SELENOPEMPHIX Benedek, 1972 emend. Bujak in Bujak et al., 1980

Selenopemphix dionaeacysta $\mathrm{n} . \mathrm{sp}$.

$$
\text { (Pl. 1, Figs. 3, 4, 7) }
$$

Selenopemphix sp. A Duffield and Stein, 1986, Pl. 1, Fig. 1. Selenopemphix sp. B Duffield and Stein, 1986, Pl. 1, Fig. 2 only. Xandarodinium? sp. cf. X. variabile Bujak 1984; Powell, 1986, Pl. 1, Fig. 7. 
Holotype. Plate 1, Figure 7. Sample 105-646B-62X-2, 139-141 cm; (1)R34/3.

Derivation of name. Named after the angiosperm Dionaea muscipula, the venus flytrap, due to the similarity between the open leaves of that plant with the cysts in certain compressions.

Diagnosis. Cysts small, polar compressed, and with a suboval to reniform outline, often with an incised parasulcus. Autophragm pale brown to medium brown and with a smooth wall surface. Paracingular folds bear processes that may have acuminate, blunt or slightly expanded or bifid tips, and some of which may be simply branched. Processes are closed distally, are hollow or partially solid, and are proximally open to the cyst cavity. Archeopyle is a large rounded hexa-intercalary and is strongly offset relative to the dorsoventral midline.

Dimensions. Holotype: maximum length of body (excluding processes), $38 \mu \mathrm{m}$. Range in maximum diameter (excluding processes), 23(33.8) $42 \mu \mathrm{m}$. Process length around 4 to $8 \mu \mathrm{m}$. Seventeen specimens were measured.

Description. The paracingular processes show considerable variability in morphology and number, and various types are found on the same cyst. Spines may be loosely clustered on indistinct lobations of the paracingular folds, (reflecting tabulation), although typically spines are fairly regularly distributed along the folds. The archeopyle was rarely observed due to the adherence of the operculum.

Discussion. This species is distinguished from others in the genus by its small size and nature of the paracingular processes. It has previously been recorded from the upper lower to upper Miocene of the Gulf of Mexico (Duffield and Stein, 1986), and from the middle to uppermost Miocene of Northwest Italy (Powell, 1986).

\section{Selenopemphix? indentata $\mathrm{n}$. sp.}

(Pl. 1, Figs. 1, 2, 5, 6)

Holotype. Plate 1, Figure 1. Sample 105-646B-67X-3, 50-53 cm; (2)K52/1.

Derivation of name. Latin indentatus, indented; with reference to the endophragm of the paracingular crests.

Diagnosis. Cysts polar compressed and having a subspherical outline. Wall closely appressed biphragmal, light brown in color, with the periphragm much thinner than the endophragm. Wall surface is smooth to faintly granulate. Appressed paracingular folds (crests) surround the cyst, except in the sulcal region. Concave rounded indentations occur in the endophragm along the distal margins of the paracingular crests. Indentations are not present in the periphragm. Archeopyle is a large rounded hexa-intercalary.

Dimensions. Holotype: maximum diameter, including crests, $44 \mu \mathrm{m}$. Range in maximum diameter, including crests, 34(41.5) $49 \mu \mathrm{m}$. Crest height up to around $5 \mu \mathrm{m}$. Nineteen specimens were measured.

Description. Each of the two paracingular crests that run around the perimeter of the cyst is considered to be an appressed fold, although it might be a thin solid crest. Indentations of the crest margin are rather irregularly spaced. They generally extend for about one-half the height of the crest. The presence of a very thin periphragm is only clearly seen around the cyst margin, where it overlies the indented portion of the endophragm. It provides the cyst with an entire equatorial margin in plan view. The archeopyle was rarely observed because of adherence of the operculum in most specimens. Based on a few observations, it appears to be a large hexa-intercalary, offset relative to the dorsoventral midline and typical of the genus Selenopemphix.

Discussion. The presence of broad, concave endophragmal indentations around the paracingular crests distinguishes this species from all other species of Selenopemphix. Both Selenopemphix and the dorsoventrally compressed Lejeunecysta were erected for autophragmal cyst species, although careful study of some of these might reveal a closely appressed biphragmal wall (M.J.H., unpublished data).

\section{INCERTAE SEDIS}

Group ACRITARCHA Evitt, 1963

Genus CYMATIOSPHAERA (Wetzel, 1933) Deflandre 1954

\section{Cymatiosphaera? invaginata $\mathrm{n} . \mathrm{sp}$.}

(Pl. 5, Figs. 13-19)

Labyrinthodinium truncatum auct. non Piasecki; Mudie, 1987, p. 804, Pl. 3, Figs. 12a, 12b, 13; Pl. 4, Figs. 14a, 14b.

?Cymatiosphaera sp.1; Mudie, in press, Pl. 3, Figs. 7, 8.

Holotype. Plate 5, Figures 13, 14. Sample 105-646B-51X-2, 21-26 $\mathrm{cm}$; (1) Q44/1.
Derivation of name. Latin invaginatus, invaginated; with respect to the inwardly folded nature of crest tops at intersections, which is a characteristic feature of this species.

Diagnosis. Small forms (cysts?) having a thin spherical central body with a smooth surface and covered with high thin folds, forming crests that divide the surface into about 20 irregularly polygonal fields. Crest wall layers thin and closely appressed, except at crest intersections where tops are conspicuously invaginated. Crest height may be constant or slightly indented between crest junctions. Dinocyst paratabulation not apparent. No aperture seen.

Dimensions. Holotype: Maximum diameter (including crests), $23 \mu \mathrm{m}$. Range in diameter (including crests), 18(21.6)25 $\mu \mathrm{m}$. Crest height, around 2 to $4 \mu \mathrm{m}$; crest thickness, $0.2-0.5 \mu \mathrm{m}$. Fifteen specimens were measured.

Remarks. The mainly appressed, two-layered nature of the crests is best observed under SEM. Under the light microscope (bright field) crests appear single layered except at crest junctions where invagination, up to $2 \mu \mathrm{m}$ deep, of the top of the crests is discernible.

Discussion. All species of the acritarch genus Cymatiosphaera known to us have solid crests; thus, the generic placement of the present species is tentative. Cymatiosphaera? invaginata $\mathrm{n}$. sp. is a dominant component of a number of samples in the interval studied. This species was recorded as "Labyrinthodinium truncatum" by Mudie (1986) from upper Miocene and lower Pliocene sediments of DSDP Leg 94, Sites 607 (central North Atlantic) and 611 (northern North Atlantic), where it was recorded frequently. Recorded also from the upper Miocene to upper Pliocene (very common in zone PM3 of upper Miocene to lowermost Pliocene) of the Norwegian Sea (as ?Cymatiosphaera sp. 1 in Mudie, in press) and recorded rarely from the middle or upper Miocene of Baffin Bay (Head et al., c, this volume).

Cymatiosphaera? baffinensis Head et al. (c, this volume) differs from Cymatiosphaera? invaginata $\mathrm{n}$. sp. in having thicker crests $(0.7$ to $1.1 \mu \mathrm{m}$ ), and rather less numerous polygonal fields (about 12 to 14 ) than for C.? invaginata $\mathrm{n}$. sp.

\section{ACKNOWLEDGMENTS}

Financial support for this project was obtained from a Natural Sciences and Engineering Research Council of Canada operating grant to G. Norris, from the Department of Energy Mines and Resources Research Agreement Nos. 66, 96, and 195 to G. Norris and M. J. Head, and from Geological Survey of Canada funding for Project 820044 to P. J. Mudie. We thank G. Gomolka (Univ, of Toronto) for his assistance with the SEM, as well as G. L. Williams and R. Fensome for their hospitality during a visit by M. J. Head to the Atlantic Geoscience Centre, Nova Scotia during this research, to A. de Vernal (Univ. of Québec à Montréal) for stimulating discussions regarding Leg 105 dinocyst taxonomy, and to A. Scholze (Univ. of Oslo), who provided helpful comments on an early version of this paper. We are especially grateful to L. E. Edwards (U.S. Geological Survey), S. P. Srivastava (Geological Survey of Canada), and an anonymous colleague, who reviewed this manuscript and provided many useful comments.

This is Geological Survey of Canada contribution 35188.

\section{REFERENCES}

Below, R., 1981. Dinoflagellaten-Zysten aus dem oberen Hauterive bis unteren Cenoman Süd-West-Marokkos. Palaeontographica, Abt. B, $176(1-4): 1-145$

Benedek, P. N., 1972. Phytoplanktonten aus dem Mittel- und Oberoligozän von Tönisberg (Niederrheingebiet). Palaeontographica, Abt. $B, 137: 1-71$.

Benedek, P. N., and Sarjeant, W.A.S., 1981. Dinoflagellate cysts from the middle and upper Oligocene of Tönisberg (Niederrheingebiet): a morphological and taxonomic restudy. Nova Hedwigia, 35:313-356.

Berggren, W. A., Kent, D. V., and Van Couvering, J. A., 1985. Neogene geochronology and chronostratigraphy. In Snelling, N .J. (Ed.), The Chronology of the Geological Record: London (Geol. Soc. London Mem.), 10:211-260.

Brown, S., 1986. Nematosphaeropsis downii sp. nov.: a new dinoflagellate cyst from Miocene sediments in the Bay of Biscay. J. Micropaleontol., 5(1):7-10.

Bujak, J. P., 1984. Cenozoic dinoflagellate cysts and acritarchs from the Bering Sea and northern North Pacific, DSDP Leg 19. Micropaleontology, 30(2):180-212. 
Bujak, J. P., Downie, C., Eaton, G. L., and Williams, G. L., 1980. Dinoflagellate cysts and acritarchs from the Eocene of southern England. Palaeontol. Assoc. London Spec. Pap., 24:26-36.

Davey, R. J., 1975. A dinoflagellate cyst assemblage from the Late Cretaceous of Ghana. Proc. Fifth West African Colloquium on Micropaleontol., Ser. 7(5):150-173.

Deflandre, G., 1954. Systèmatiques des Hystrichosphaeridés: sur l'acception du genre Cymatiosphaera 0. Wetzel. C. R. Som. Soc. Géol. Fr., 12:257-258.

Deflandre, G., and Cookson, I. C., 1955. Fossil microplankton from Australian late Mesozoic and Tertiary sediments. Austral. J. Mar. Freshwater Res., 6:242-313.

Duffield, S., and Stein, J. A., 1986. Peridiniacean-dominated dinoflagellate cyst assemblages from the Miocene of the Gulf of Mexico shelf, offshore Louisiana. Am. Assoc. Strat. Palynol. Contrib. Ser., $17: 27-46$.

Edwards, L. E., 1984. Miocene dinocysts from Deep Sea Drilling Project Leg 81, Rockall Plateau, eastern North Atlantic Ocean. In Roberts, D. G., Schnitker, .., et al., Init. Repts. DSDP, 81: Washington (U.S. Govt. Printing Office), 581-594.

Erdtman, G., 1969. Handbook of Palynology: An Introduction to the Study of Pollen Grains and Spores: Copenhagen (Munksgaard), 1-486.

Evitt, W. R., 1963. A discussion and proposals concerning fossil dinoflagellates, hystrichospheres, and acritarchs. Proc. Nat. Acad. Sci. (U.S.), 49:158-164.

Fenton, J.P.G., Neves, R., and Piel, K. M., 1980. Dinoflagellates and acritarchs from upper Bajocian to middle Bathonian strata of central and southern England. Palaeontology, 23:151-170.

Fritsch, F. E., 1929. Evolutionary sequence and affinities among Protophyta. Biol. Rev., 4:103-151.

Habib, D., 1976. Neocomian dinoflagellate zonation in the western North Atlantic. Micropaleontology, 21:373-392.

Haeckel, E., 1894. Entwurf eines natürlichen Systems der Organismen auf Grund ihrer Stammegeschichte, Erster Teil: Systematische Phylogenie der Protisten und Pflanzen: Berlin (Georg Reimer), 1-400.

Harland, R., 1979. Dinoflagellate biostratigraphy of Neogene and Quaternary sediments at Holes 400/400A in the Bay of Biscay (Deep Sea Drilling Project Leg 48). In Montadert, L., Roberts, D. G., et al., Init. Repts. DSDP, 48: Washington (U.S. Govt. Printing Office), 531-545.

Jan du Chêne, R., 1977. Etude palynologique du Miocène supérieur Andalou (Éspagne). Rev. Espanola Micropaleontol., 9:97-114.

Jan du Chêne, R., Masure, E., Becheler, I., Biffi, U., et al., 1986. Guide pratique pour la détermination de kystes de Dinoflagellés fossiles: le complex Gonyaulacacysta. Bull. Centres Rech. Explor.Prod. Elf-Aquitaine Mem., 12:1-479.

Lentin, J. K., and Williams, G. L., 1985. Fossil dinoflagellates: index to genera and species, 1985 Edit. Can. Tech. Rep. Hydrogr. Ocean Sci., 60:1-451.

Matsuoka, K., 1983. Late Cenozoic dinoflagellates and acritarchs in the Niigata District, central Japan. Palaeontographica, Abt. B, 187:89154.
Matsuoka, K., Bujak, J. P., and Shimazaki, T., 1987. Late Cenozoic dinoflagellate cyst biostratigraphy from the west coast of North Japan. Micropaleontology, 33(3):214-229.

McCave, I. N., and Tucholke, B. E., 1986. Deep current controlled sedimentation in the western North Atlantic. In Vogt, P. R., and Tucholke, B. E. (Eds.), The Geology of North America, Vol. M, The Western North Atlantic Region. Geol. Soc. Am., 451-468.

Mudie, P. J., 1987. Palynology and dinoflagellate biostratigraphy of Deep Sea Drilling Project Leg 94, Sites 607 and 611, North Atlantic Ocean. In Ruddiman, W. F., Kidd, R. B., Thomas, E., et al., Init. Repts. DSDP, 94: Washington (U.S. Govt. Printing Office), 785812 .

in press. Palynology and dinocyst biostratigraphy of the late Miocene to Pleistocene, Norwegian Sea, ODP Leg 104, Sites 642 to 644. In Eldholm, 0., Thiede, J., et al., Proc. ODP, Sci. Results, 104: College Station, TX (Ocean Drilling Program).

Pascher, A., 1914. Über Flagellaten und Algen. Deutschen Bot. Gesell. Berlin, 36:136-160.

Piasecki, S., 1980. Dinoflagellate cyst stratigraphy of the Miocene Hodde and Gram Formations, Denmark. Geol. Surv. Denmark Bull., 29: 53-76.

Powell, A. J., 1986. The stratigraphic distribution of late Miocene dinoflagellate cysts from the Castellanian superstage stratotype, Northwest Italy. Am. Assoc. Strat. Palynol. Contrib. Ser., 17:129-149.

Stover, L. E., and Evitt, W. R., 1978. Analyses of Pre-Pleistocene Organic-Walled Dinoflagellates: Palo Alto (Stanford Univ. Publications), Geol. Sci., 15:1-300.

Stover, L. E., and Williams, G. L., 1987. Analyses of Mesozoic and Cenozoic organic-walled dinoflagellates. Am. Assoc. Strat. Palynol. Contrib. Ser., 18:1-243.

Wall, D., 1967. Fossil microplankton in deep-sea cores from the Caribbean Sea. Palaeontology, 10:95-123.

Wetzel, 0., 1933. Die in organischer Substanz erhaltenen Mikrofossilien des baltischen Kreidefeuersteins. Palaeontographica Abt. A, 77: $141-188$ and $78: 1-110$.

Williams, G. L., and Downie, C., 1966. Further dinoflagellate cysts from the London Clay. In Davey, R. J., Downie, C., Sarjeant, W.A.S., and Williams, G. L. (Eds.), Studies on Mesozoic and Cainozoic Dinoflagellate Cysts: London (Bull. Br. Museum Nat. Hist., Geol. Suppl., 3:215-235.

Wilson, G. J., 1973. Palynology of the middle Pleistocene Te Piki bed, Cape Runaway, New Zealand. New Zealand J. Geol. Geophys., 16: 45-354.

Wrenn, J. H., and Kokinos, J. P., 1986. Preliminary comments on Miocene through Pleistocene dinoflagellate cysts from De Soto Canyon, Gulf of Mexico. Am. Assoc. Strat. Palynol. Contrib. Ser., 17:169225 .

Date of initial receipt: 7 January 1988

Date of acceptance: 7 June 1988

Ms B105-136 


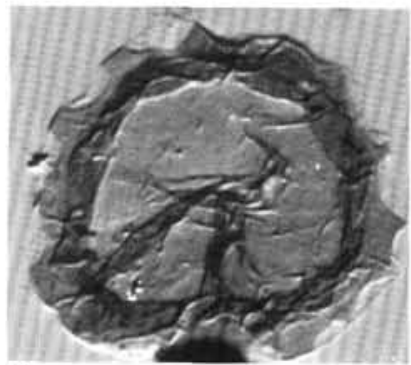

1

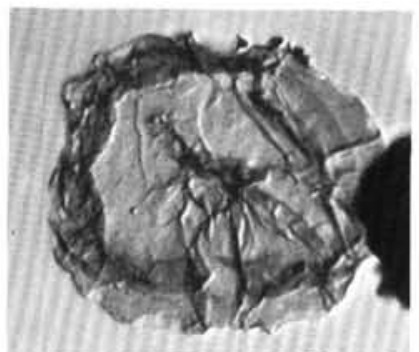

5

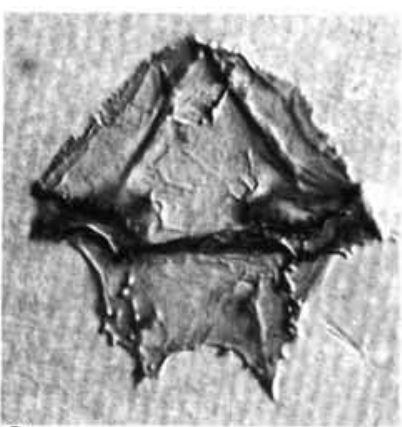

9

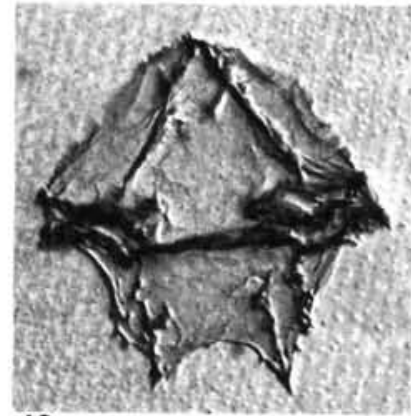

13

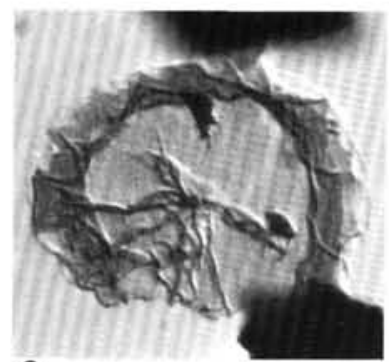

2

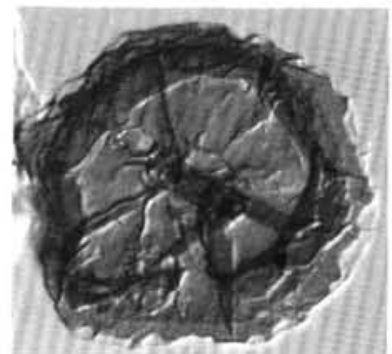

6

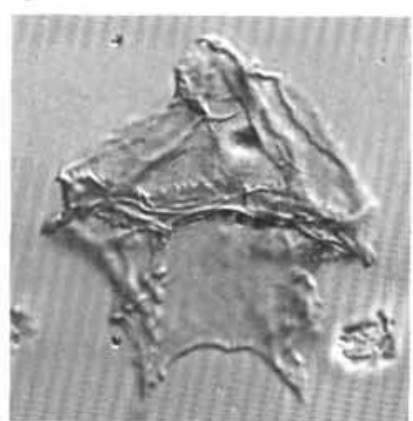

10

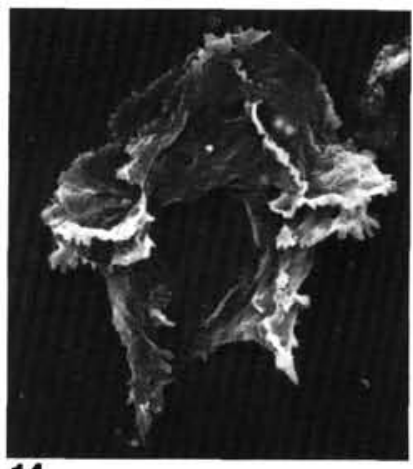

14

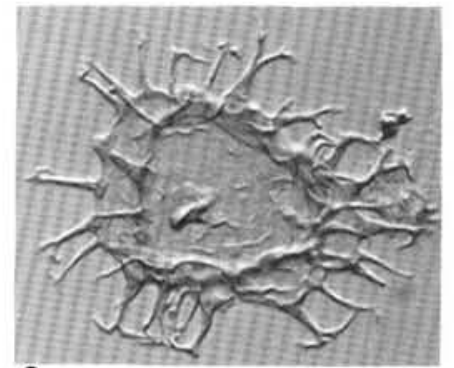

3

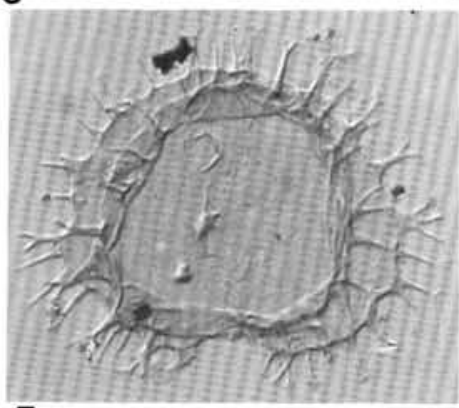

7

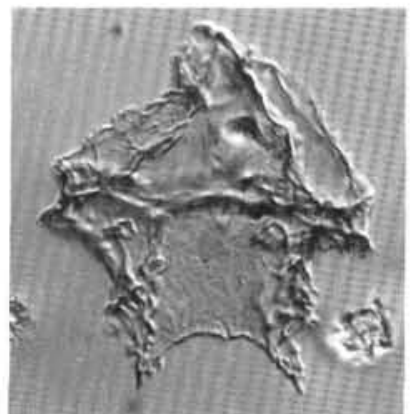

11

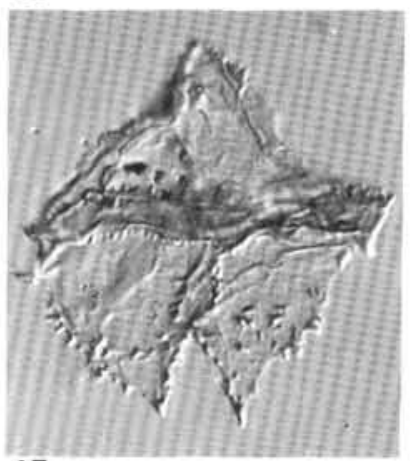

15

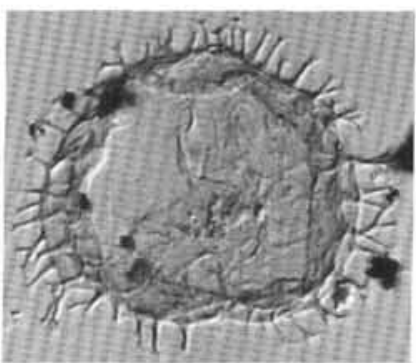

4

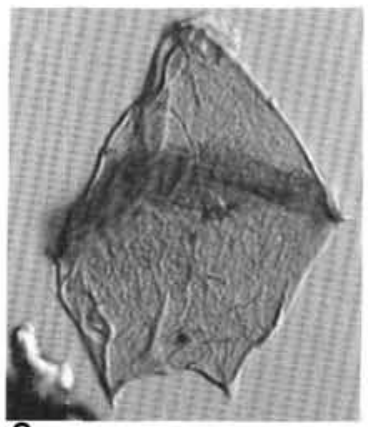

8

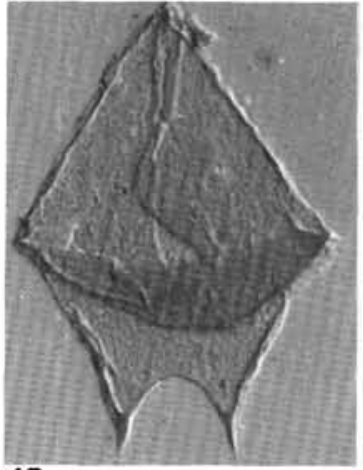

12

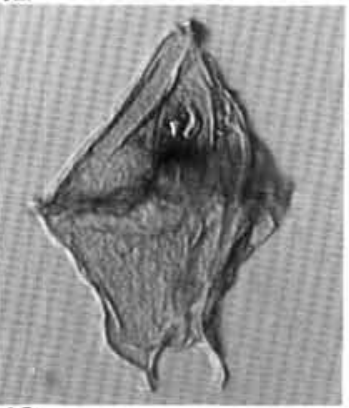

16

Plate 1. (Figs. 1-13, 15, 16, IC; Fig. 14, SEM) 1, 2, 5, 6, Selenopemphix? indentata n. sp. (Figs. 1, 2, 5, 6, uncertain views; Figs. 1, 6, upper focus; Figs. 2, 5, midfocus). 1. Holotype, Sample 105-646-67X-3, 50-53 cm (2)K52/1; diameter, $44 \mu \mathrm{m}$ (including crests). 2. Sample 105-646-67X-3, $50-53 \mathrm{~cm}$ (1)M45/0; diameter, $41 \mu \mathrm{m}$ (including crests), note offset archeopyle. 5. Sample 105-646-67X-3, 50-53 cm (2)E45/3; diameter, 41 $\mu \mathrm{m}$ (including crests). 6. Sample 105-646-67X-3, 50-53 cm (2)E41/4; diameter, $41 \mu \mathrm{m}$ (including crests). 3, 4, 7, Selenopemphix dioneaecysta $\mathrm{n}$. sp.; (Fig. 7, antapical view; Fig. 3, antapical? view; and Fig. 4, uncertain view; Figs. 3,4,7, midfocus). 3. Sample 105-646-76X, CC (6)F47/3; diameter, 32 $\mu$ m (body only). 4. Sample 105-646-65X-3, 101-104 cm (1)Q25/4; diameter, $35 \mu \mathrm{m}$ (body only), note archeopyle. 7. Holotype, Sample 105-646-62X-2, 139-141 cm (1)R34/3; diameter, $42 \mu \mathrm{m}$ (body only). 8, 12, 16. Cristadinium diminutivum n. gen, n. sp.; (Figs. 8, 12, 16, uncertain views; Figs. 8,16, upper focus; Fig. 12, midfocus.) 8. Holotype, Sample 105-646-65X-3, 101-104 cm (1)F32/0; length, $45 \mu$ m. 12. Sample 105-646-65X-3, 101-104 cm (1)R11/1; length, $42 \mu \mathrm{m}$. 16. Sample 105-646-71X-2, 125-127 cm (1)U52/0; length, $54 \mu \mathrm{m}$. 9-11, 13-15. Cristadinium cristatoserratum n. gen., n. sp.; Figs. 9, 11, 13, dorsal view of ventral surface; Figs. 10, 15, dorsal view of dorsal surface; Fig. 14, ventral view of ventral surface.) 9, 13. Sample 105-646-67X-3, 50-53 cm (2)X13/2; length, $22 \mu \mathrm{m} .10,11$. Holotype, Sample 105-646-80X, CC (2)U22/2; length, $44 \mu \mathrm{m}$. 14. Sample 105-646-80X, CC (stub 1); $1100 \times$. 15. Sample 105-646-80X, CC (2)L54/0; length, $43 \mu \mathrm{m}$. 


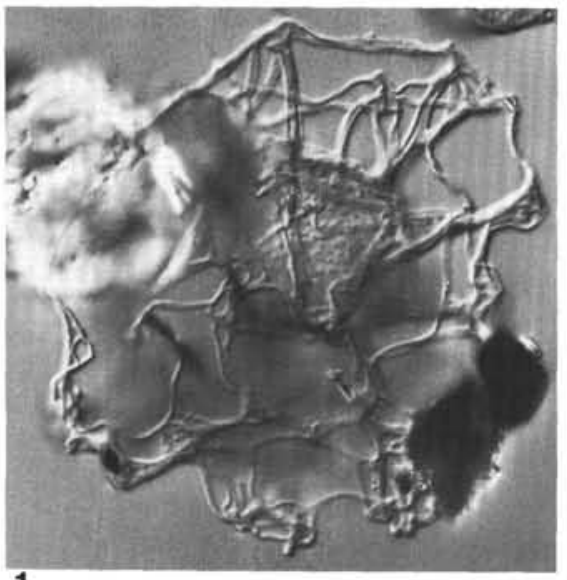

1

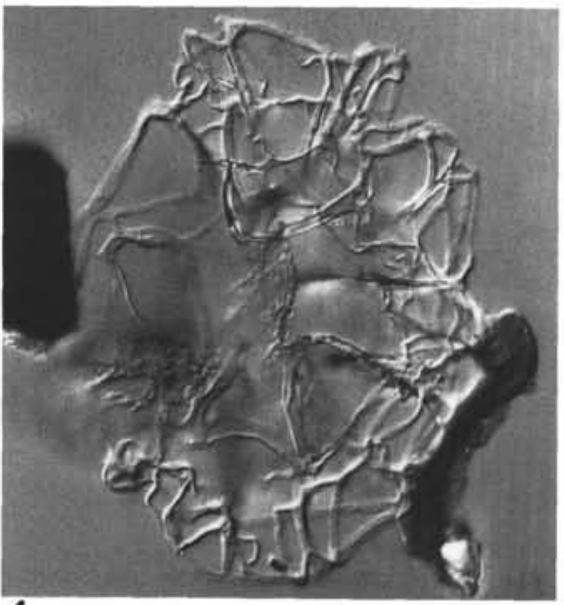

4

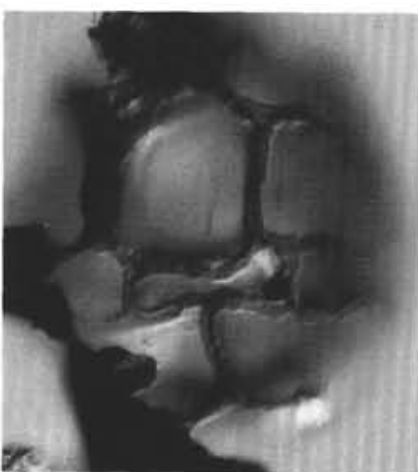

11

12

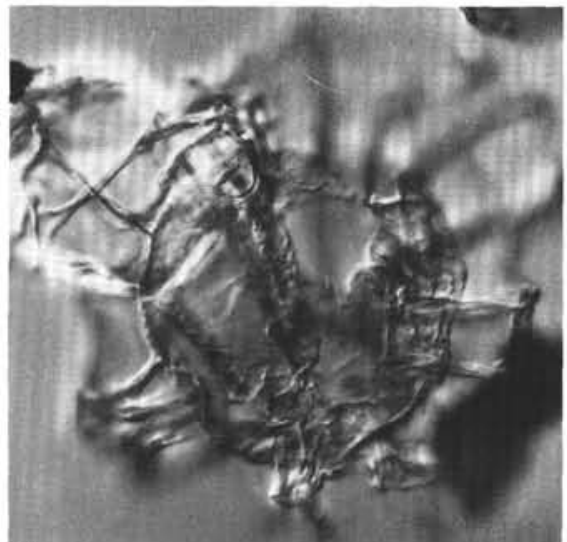

2

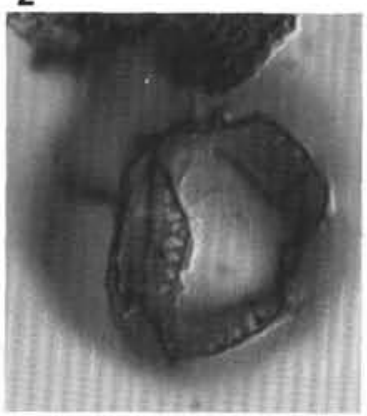

5

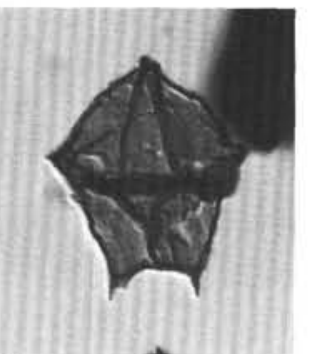

8

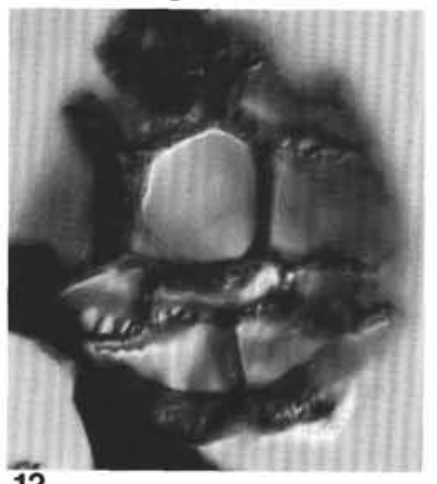

6

9

13

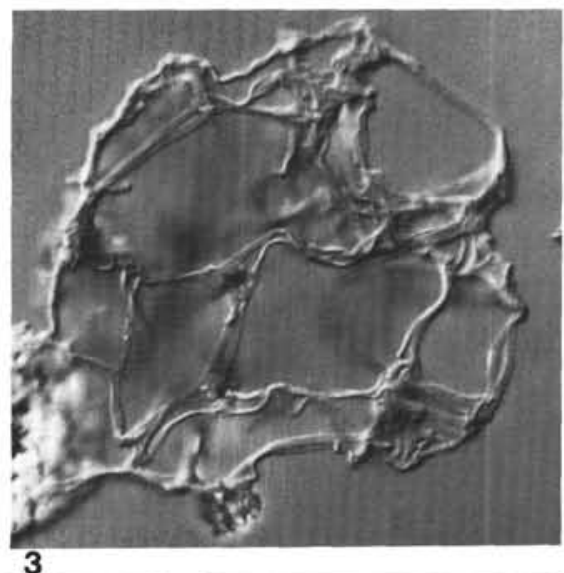

3
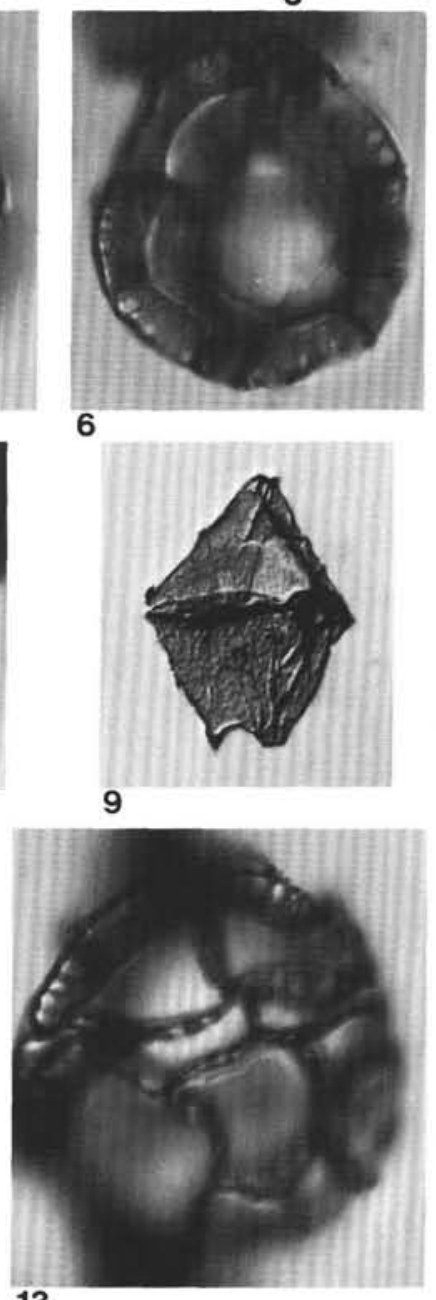

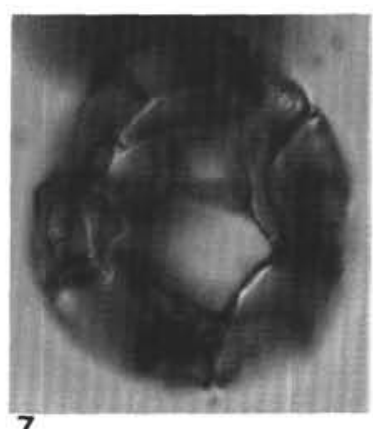

7

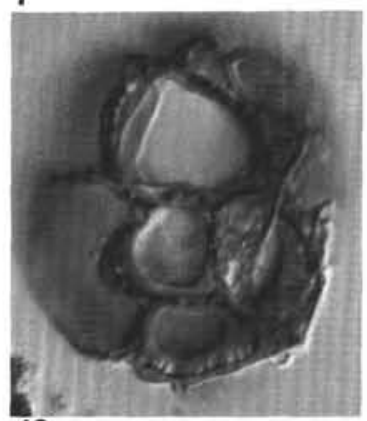

10

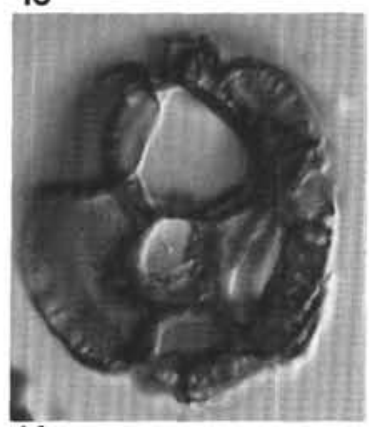

14

Plate 2. (All Figs. IC) 1-4, Nematosphaeropsis major n. sp.; Figs. 1, 2, ventral view of ventral surface; Fig. 3, dorsal view of dorsal surface; Fig. 4, left-dorsal view of dorsal surface. 1, 2. Holotype, Sample 105-646-80X-2, 2-4 cm (1)Q13/1; central body diameter, 50 $\mu \mathrm{m}$. 3. Sample 105-646-80X-2, 2-4 $\mathrm{cm}$ (1)H18/0; central body diameter, $47 \mu \mathrm{m}$. 4. Sample 105-646-80X-2, 2-4 cm (2)L29/1; central body diameter, 49 $\mu \mathrm{m}$. 5-7, 10-14. Impagidinium fenestroseptatum n. sp.; (Figs. 5, 6, 7, 10, 14, orientation uncertain; Fig. 5, upper surface; Fig. 6, midfocus; Fig. 7, lower surface; Fig. 10, upper surface; Fig. 14, upper surface, lower focus; Figs. 11, 12, dorsal? view of dorsal? surface; Fig. 13, dorsal? view of ventral? surface.) 5-7. Sample 105646-51X-2, 21-26 cm (2)S48/0; diameter, $54 \mu$ m (including crests). 10, 14. Sample 105-646-51X-2, 21-26 cm (2)E48/2; diameter, $57 \mu \mathrm{m}$ (including crests). 11-13. Holotype, Sample 105-646-51X-2, 21-26 cm (2)N34/0; diameter, $65 \mu \mathrm{m}$ (including crests). 8, 9. Cristadinium diminutivum n. gen., n. sp.; Figs. 8, 9, view uncertain, midfocus. 8. Sample 105-646-71X-2, 125-127 cm (1)032/2; length, $31 \mu \mathrm{m}$. 9. Sample 105-646-67X-3, 50-53 cm (2)T29/3; length, $38 \mu \mathrm{m}$. 


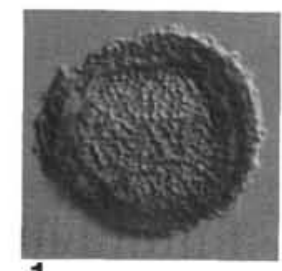

1

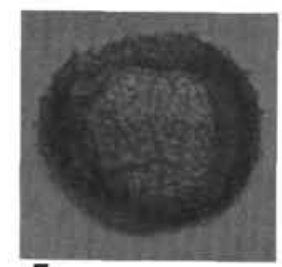

5

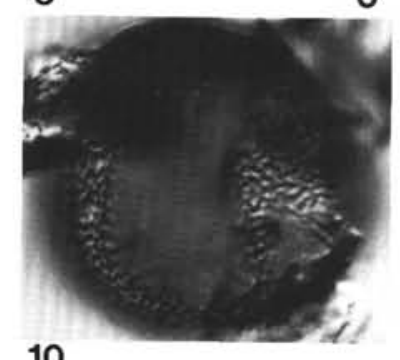

10

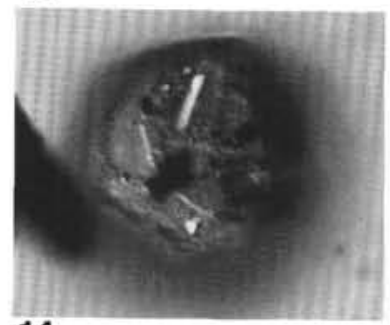

14

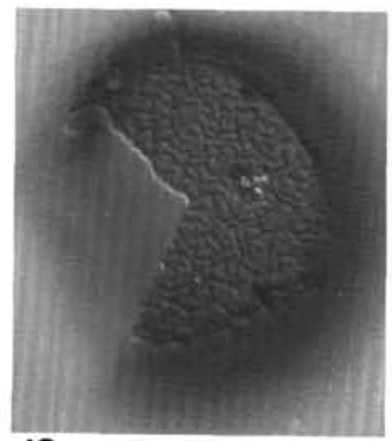

18

2

6
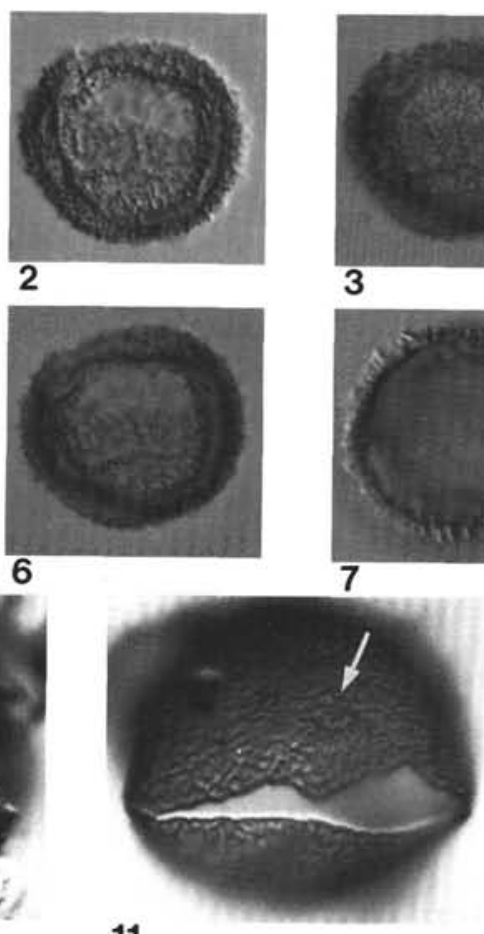

11

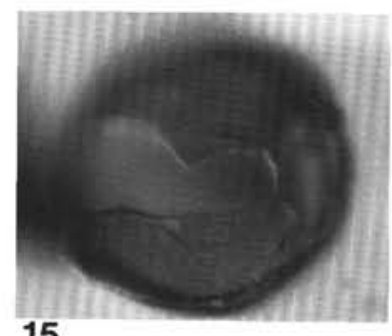

15

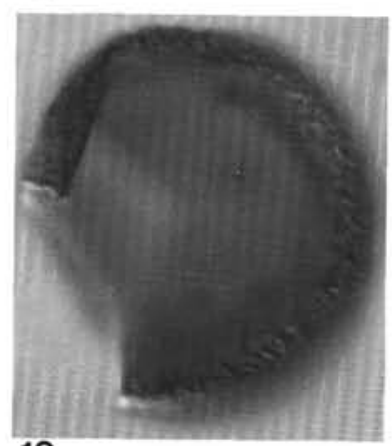

19

3

7
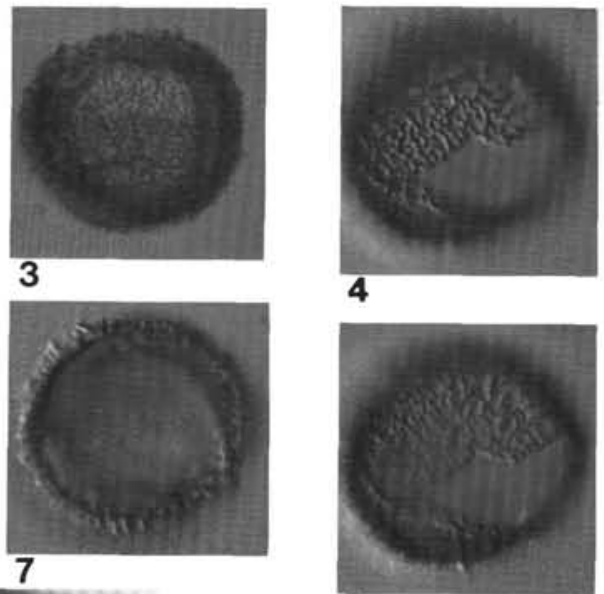

8

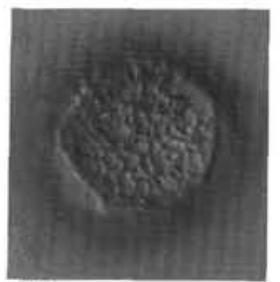

12

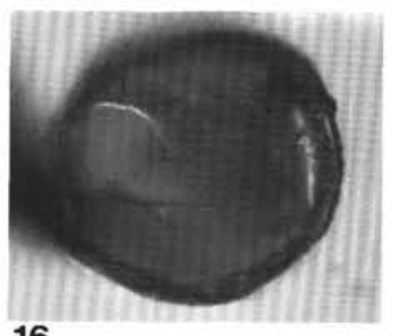

16

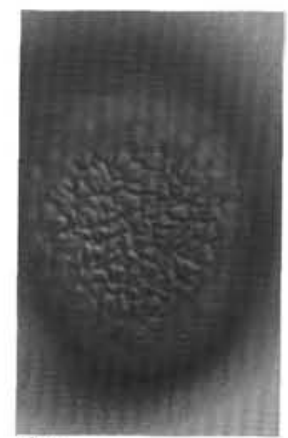

20

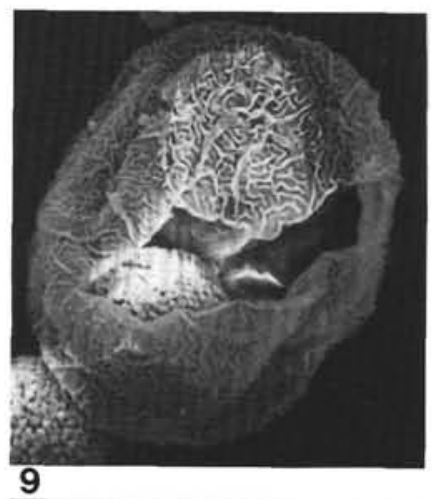

9

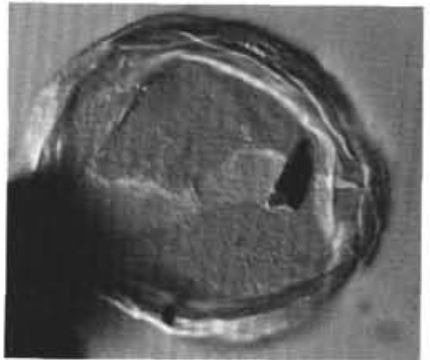

13

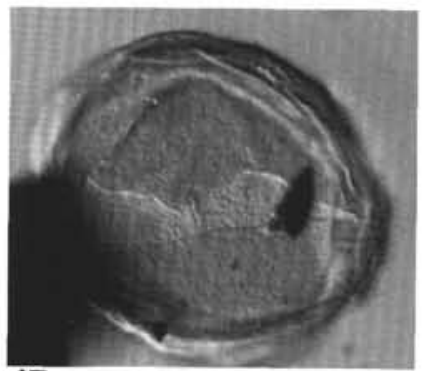

17

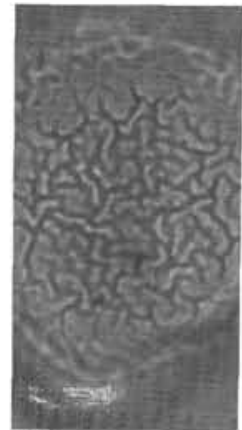

21

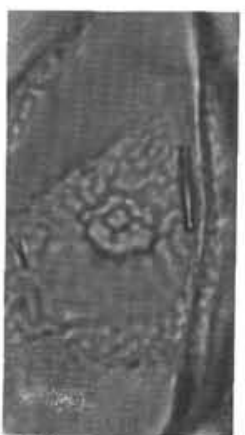

22

Plate 3. (Figs. 1, 2, 4, 7, 8, 10-20, IC; Figs. 3, 5, 6, 21, 22, BF; Fig. 9, SEM). 1-9, 12. Corrudinium? labradori $\mathrm{n}$. sp.; Figs. 1-8, 12, ventral views; Figs. 1, 3, 5, 12 ventral surface; Figs. 2, 4, 6, 8 dorsal surface; Fig. 7, midfocus. Fig. 9, dorsal view of dorsal surface.) 1-3, 5-6. Holotype, Sample 105-646-51X-2, 21-26 cm (1)041/3; diameter, $27 \mu \mathrm{m}$. 4, 7, 8, 12. Sample 105-646-51X-2, 21-26 cm (1)E42/0; diameter, 30 $\mu \mathrm{m}$. 9. Sample 105-646-80X, CC (stub 1); $1180 \times . \quad 10,11,18-22$, Cerebrocysta? namocensis n. sp.; Figs. 10, 11, 21, ventral views; Figs. 10, 21, ventral surface; Fig. 11, dorsal surface; Figs. 18-20, right-lateral views; Fig. 18, upper surface; Fig. 19, midfocus; Fig. 20, lower surface; Fig. 21, antapical view, apical surface.) 10, 11. Holotype, Sample 105-646-67X, CC (1)P15/0; diameter, $46 \mu \mathrm{m}$ (note arrow indicating apical ring structure in Fig. 11). 18-20. Sample 105-646-67X, CC (1)V24/0; diameter. $48 \mu \mathrm{m}$. 21. Sample 105-646-67X, CC (4)G50/1; cyst diameter, $48 \mu \mathrm{m}$; scale bar, $5 \mu \mathrm{m}$. 22. Sample 105-646-67X, $\mathrm{CC}$ (1)P16/4; cyst diameter, $40 \mu \mathrm{m}$; scale bar, $5 \mu \mathrm{m}$ (note apical ring structure). 14-16. Gongylodinium serratum n. sp. Figs. 14-16, ventral views; Fig. 14, ventral surface; Figs. 15, 16, dorsal surface. Figs. 14-16. Holotype, Sample 105-646-80X-2, 2-4 cm (1)H35/2; diameter, $40 \mu \mathrm{m}$. 13 , 17 . Gongylodinium sp. cf. G. serratum n. sp. Figs. 13, 17, dorsal views; Fig. 13, ventral surface; Fig. 17, dorsal surface). Sample 105-646-73X-1, 61-64 $\mathrm{cm}(1) \mathrm{E} 16 / 0$; diameter, $49 \mu \mathrm{m}$. 


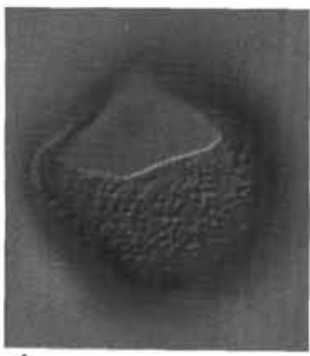

1

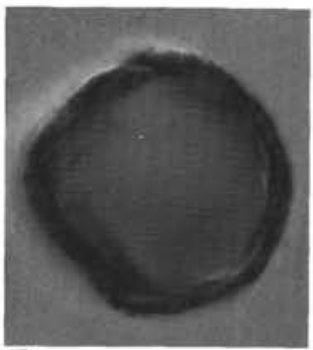

5

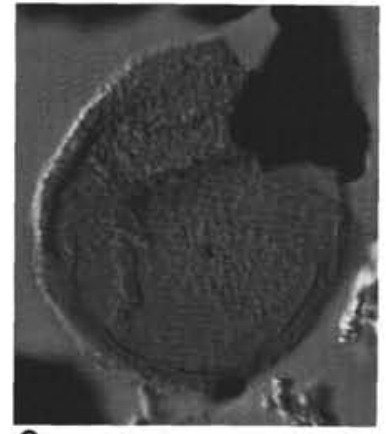

9

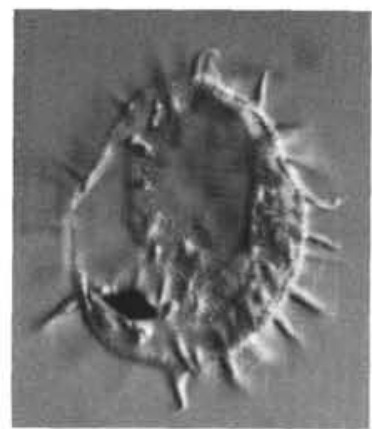

13

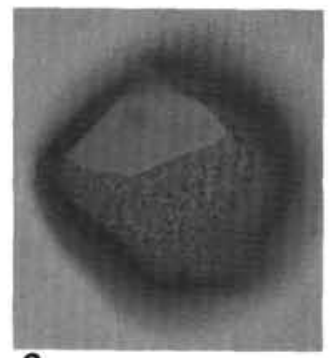

2

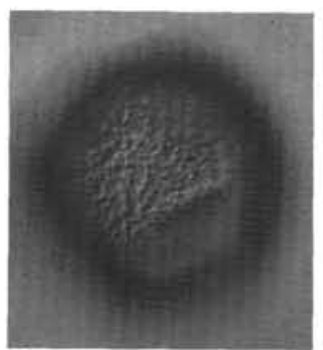

6

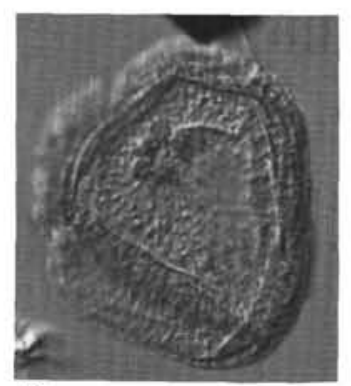

3

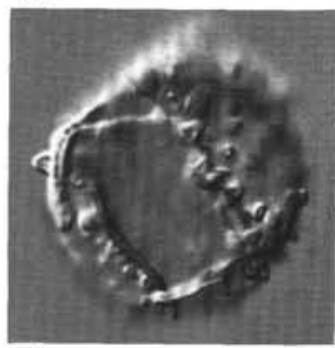

7

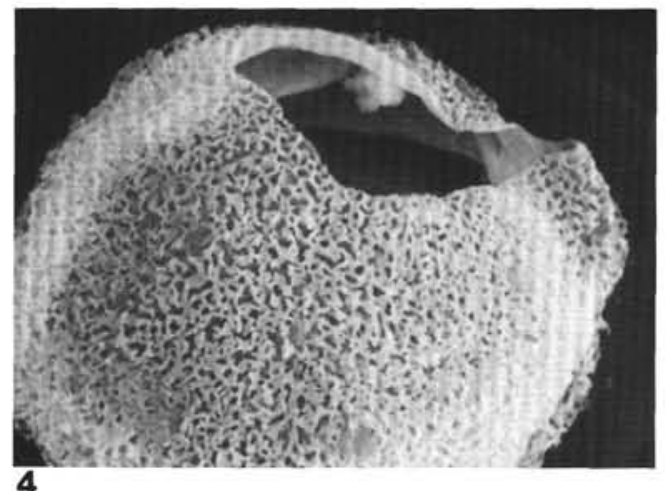

4

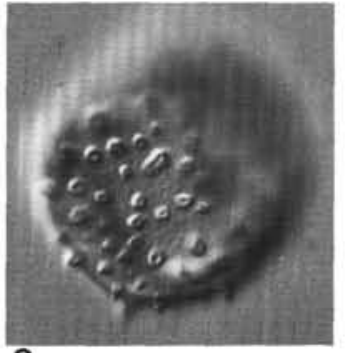

8

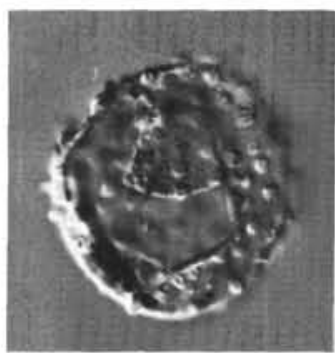

12

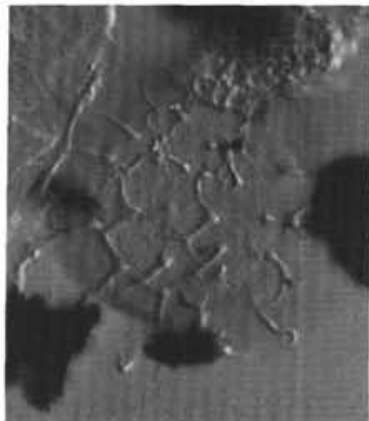

16

Plate 4. (Figs. 1, 3, 5-9, 11-16, IC.; Figs. 2, 10, BF; Fig. 4, SEM.) 1-6, 9, 10. Habibacysta tectata n. gen., n. sp.; Figs. 1, 2-5, 6, dorsal views; Figs. 1, 2, dorsal surface; Fig. 5, midfocus; Fig. 6, ventral view. Figs. 3, 4, 9, 10, lateral views of upper surface. Figs. 1, 2, 5, 6. Holotype, Sample 105-646$69 \mathrm{X}, \mathrm{CC}(5-8 \mathrm{~cm})$ (2)S42/4; diameter, $33 \mu \mathrm{m}$. 3. Sample 105-646-55X, CC (1)Q27/0; diameter, $40 \mu \mathrm{m}$. 4. Sample 105-646-80X, CC (stub 1); 2070×. 9, 10. Sample 105-646-69X, CC $(5-8 \mathrm{~cm})(1) \mathrm{R} 18 / 1$; diameter, $42 \mu \mathrm{m} .7,8,12$. Operculodinium janduchenei $\mathrm{n}$. sp.; Figs. 7, 8, dorsal/right-lateral view; Fig. 7 upper surface; Fig. 8, lower surface. Fig. 12, dorsal view of dorsal surface.) 7, 8. Holotype, Sample 105-646-78X, CC (1-3 cm) (6)F47/2; diameter (excluding processes), $31 \mu \mathrm{m}$. 9. Sample 105-646-71X-2, 125-127 cm (1)S39/0; diameter (excluding processes), 30 $\mu \mathrm{m}$. 11, 13-16. Operculodinium? eirikianum n. sp.; Figs. 11, 15, 16, ventral view; Fig. 11, dorsal surface; Fig. 15, midfocus; Fig. 16, ventral surface. Figs. 13, 14, dorsal view; Fig. 13, midfocus; Fig. 14, dorsal surface). 11, 15, 16. Holotype, Sample 105-646-66X-2, 20-23 cm (1)V15/4; body diameter, $34 \mu \mathrm{m}$. $13,14$. Sample 105-646-80X-2, 2-4 cm (4)T31/0; body diameter, $35 \mu \mathrm{m}$. 


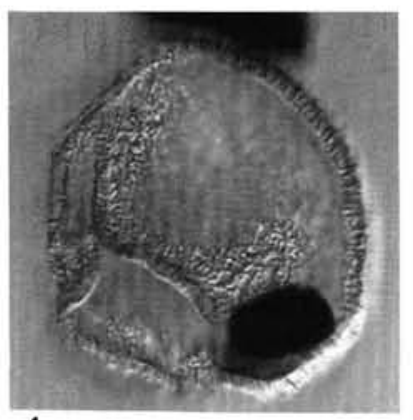

1

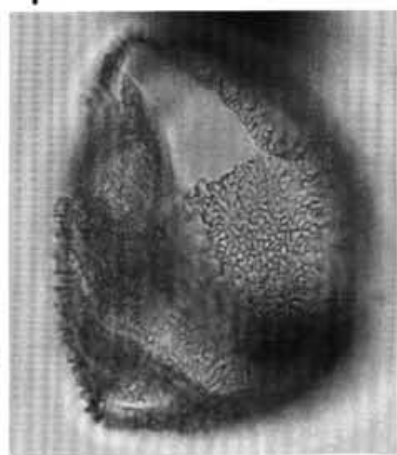

5

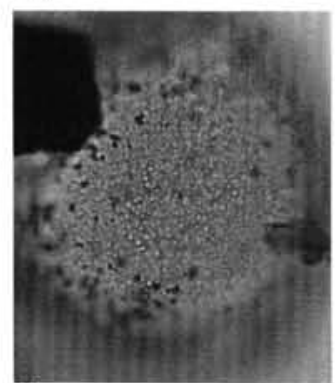

9

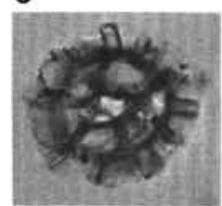

13

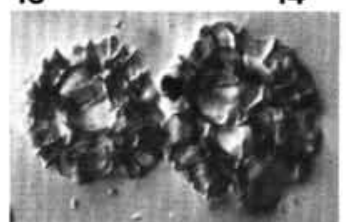

15

10

14

16

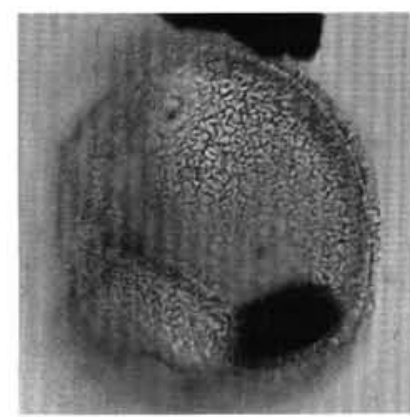

2

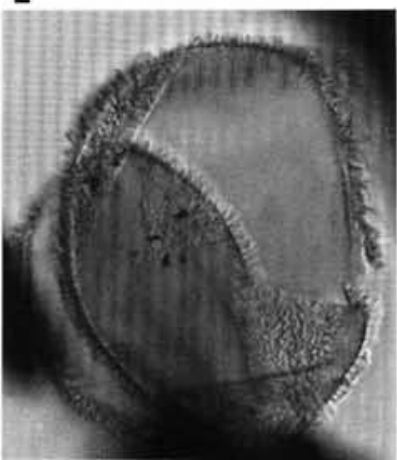

6
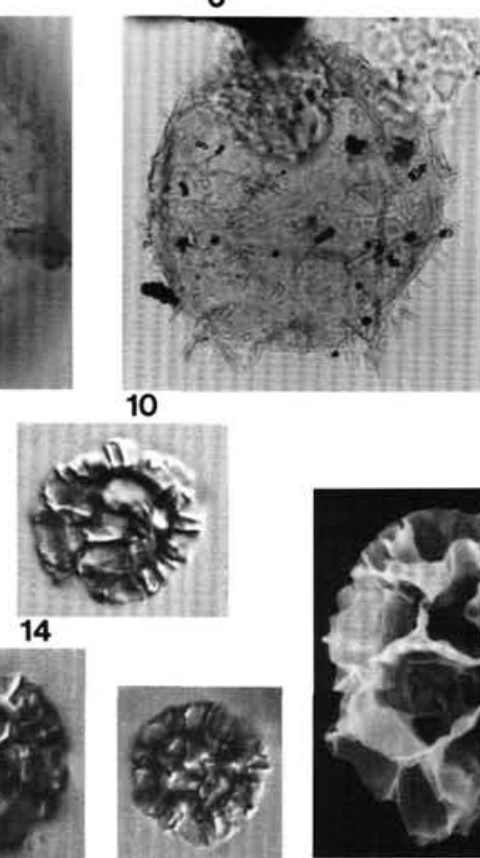

11

17

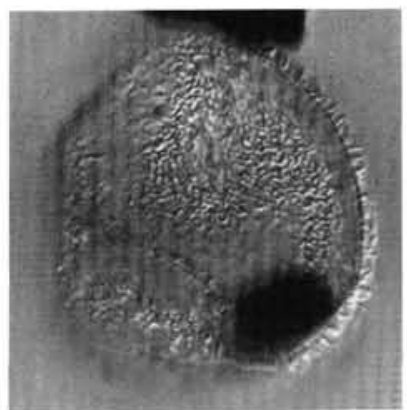

3
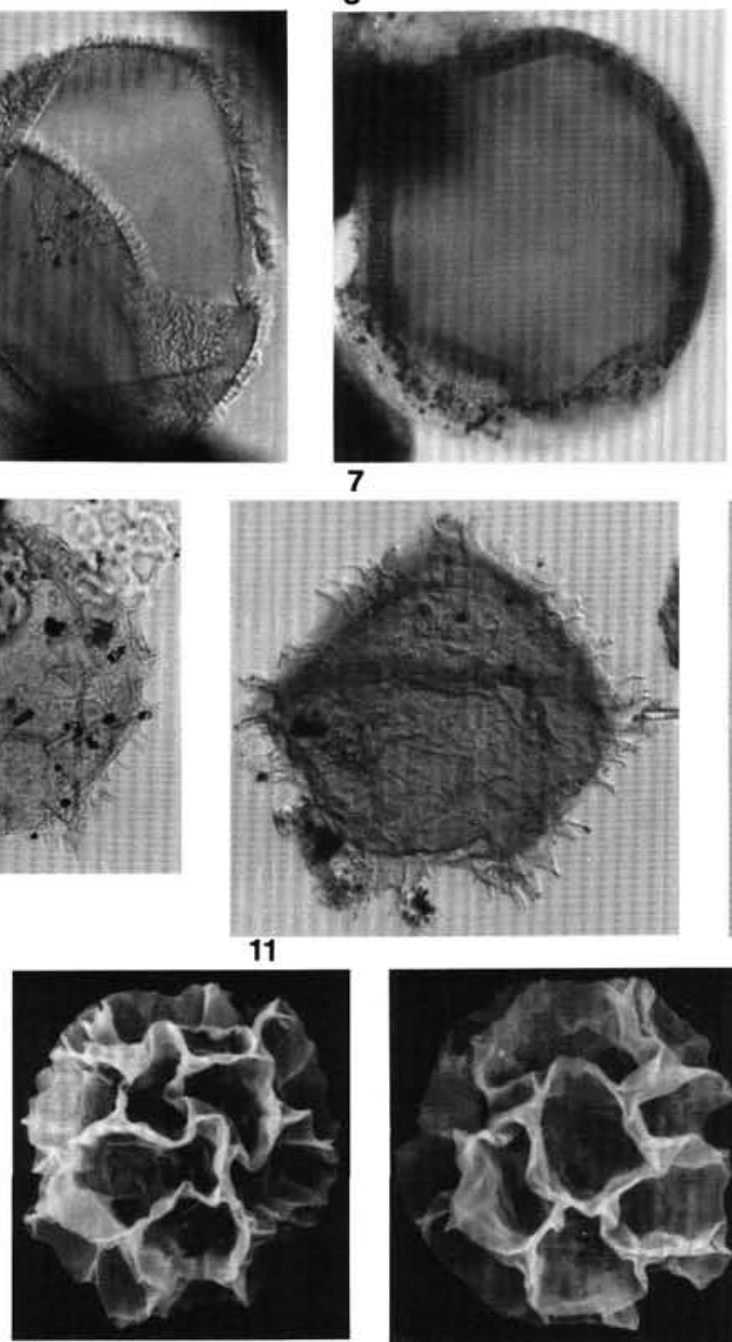

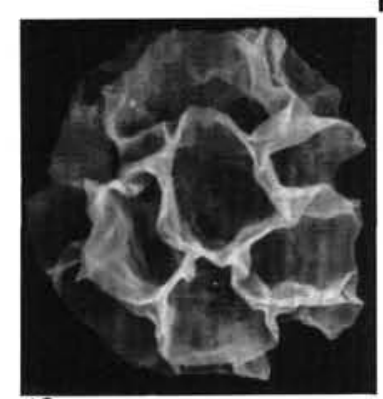

18

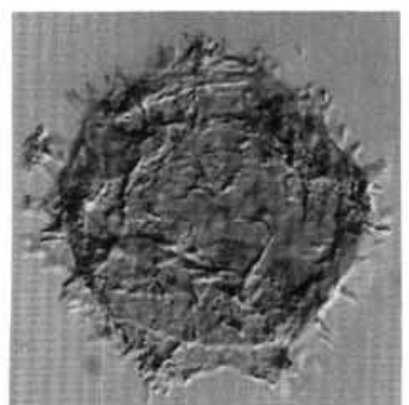

4

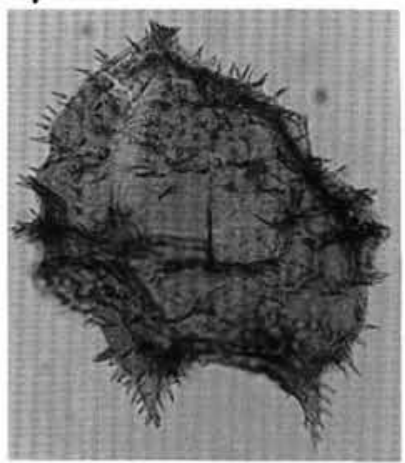

8

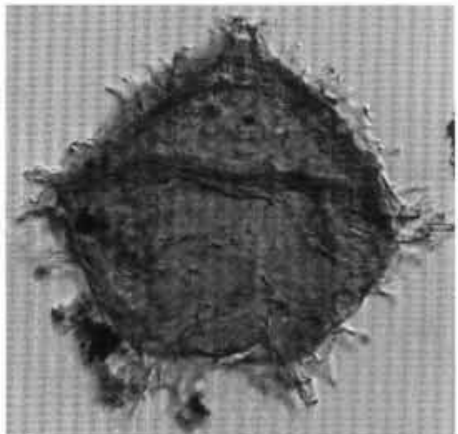

12

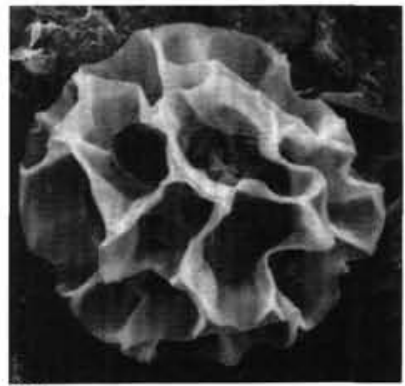

19

Plate 5. (Figs. 1, 3, 4, 6, 11, 12, 14-16, IC; Figs. 2, 5, 7-10, 13, BF; Figs. 17-19, SEM) 1-3, 5-6. Muraticysta microornata n. gen., n. sp.; Figs. 1-3, 5, ventral views; Figs. 1-3, ventral surface; Fig. 5, dorsal surface; Fig. 6, uncertain orientation). 1-3, 5. Holotype, Sample 105-646-51X-2, 21-26 cm (1)G20/0; diameter, $56 \mu \mathrm{m}$. 6. Sample 105-646-51X-2, 21-26 cm (1)H21/4; diameter, $59 \mu \mathrm{m}$. 7, 9. Filisphaera? sp. cf. F. filifera; Figs. 7, 9, rightlateral views; Fig. 7, midfocus; Fig. 9, upper surface). 7, 9. Sample 105-646-56X-3, 1-3 cm (1)M50/2; diameter, 58 $\mu$ m. 4, 8, 10-12, Capillicysta gloriana $\mathrm{n}$. sp., orientation uncertain.) 4. Sample 105-646-61X-1, 123-126 cm (1)S20/4; pericyst length, $47 \mu \mathrm{m}$. 8. Sample 105-646-78X, CC (5)P30/3; pericyst length, $69 \mu \mathrm{m}$. 10. Sample 105-646-65X-3, 101-104 cm (1)D30/0; pericyst length, $56 \mu \mathrm{m}$. 11, 12. Holotype (Fig. 11, upper [ventral?] surface; Fig. 12, lower dorsal surface). Sample 105-646-62X-2, 139-141 cm (2)G46/2; pericyst length, $63 \mu \mathrm{m}$. 13-19. Cymatiosphaera? invaginata n. sp.; orientation unknown.) 15. Sample 105-646-51X-2, 21-26 cm (1)V46/2; diameter (including crests), $27 \mu \mathrm{m}$ (larger specimen). 13, 14. Holotype, Sample 105-646-51X-2, 21-26 cm (1)Q44/1; diameter (including crests), $23 \mu \mathrm{m}$. 16. Sample 105-646-51X-2, 21-26 cm (1)Q44/0; diameter (including crests), $19 \mu \mathrm{m}$. 17. Sample 105-646-51X, CC (stub 1); 1710×. 18. Sample 105-646-51X, CC (stub 1); 1920×. 19. Sample 105-646-51X, CC (stub 1); 1710× (central body wall slightly corroded). 